\title{
BİNGAZI'DE MEYDANA GELEN KURAKLIK VE ETKİLERİ: KITLIK VE GÖÇ (1892-1893)
}

\author{
DROUGHT AND ITS EFFECTS IN BENGHAZI: FAMINE AND \\ EMIGRATION (1892-1893)
}

Metin MENEKŞE*

\begin{abstract}
$\ddot{O} z$
Farklı iklimleri ve arazi şartların bünyesinde barındıran Osmanlı Devleti, hiçbir zaman doğal afetlere uzak kalamamıştır. Osmanlı coğrafyasında görülen kıtlıklar, depremler, yangınlar, çekirge istilaları, şiddetli yă̆murlar ve kışlar, insan hayatını ciddi şekilde tehdit etmiştir. Nitekim bu doğal afetlerden biri olan kuraklık, etkili olduğu bölgede kırsal hayatı ve bu alandaki iktisadi faaliyetleri önemli derecede etkilemiştir. Bu çalışmada, 1892-1893 yıllarında Bingazi'de görülen kuraklık ve bunun halka yansıması üzerinde durulmuştur. Nitekim Bingazi'de tarihin değişik dönemlerinde kuraklık ve buna bă̆lı olarak kıtlık olaylarıyla karşılaşılmıştır. Yaşanan bu hadiseler tarımsal üretimi etkilemiş ve tarım alanında geçimini sağlayan ahaliyi zor durumda bırakmıştır. Zor şartlar altında yaşam mücadelesi veren ahaliden bir kısmı ise kuraklık olaylarının yaşanmadığ $ı$ kasabalara ya da çevre vilayetlere göç etmek zorunda kalmıştır. Bu süreçte hem merkezi yönetimden hem de çevre vilayetlerden bölgeye yemeklik ve tohumluk zahire gönderilmesine çalışılmıştır. İhtiyaç sahibi ahalinin bulunduğu mahallerde yardım komisyonlarının kurulması, yardım biletlerinin basılması, zengin insanların yardımlarının sağlanması, bazı vergilerin ertelenmesi gibi yollara başvurularak kuraklıkla mücadele edilmiştir.
\end{abstract}

\section{Anahtar Kelimeler}

Osmanlı Devleti, Bingazi, Kuraklık, Kıtlık, Zorunlu Göç, Yardımlar.

\begin{abstract}
The Ottoman State, which incorporates different climates and land conditions, has never stayed away from natural disasters. Famine, earthquakes, fires, grasshopper invasions, heavy rains and winters in the Ottoman geography threatened human life seriously. As a matter of fact, drought, which is one of these natural disasters, has affected rural life and economic activities in this area significantly. In this study, the drought seen in Benghazi in 1892-1893 and its reflection on the public were discussed. In Benghazi, there were drought and famine events in different periods of history. These events affected agricultural production and left the people in a difficult situation in the field of agriculture. Some of the people struggling to survive under difficult conditions had to emigrate to towns or surrounding provinces where drought events did not occur. In this process, both
\end{abstract}

* Dr., Muğla Sıtkı Koçman Üniversitesi Edebiyat Fakültesi Tarih Bölümü, m.menekse@mu.edu.tr, ORCID: https://orcid.org/0000-0003-1192-3161 
the central government and the surrounding provinces were tried to send to the region for edible and seed grains. Drought was fought by means of establishing aid commissions, printing aid tickets, providing assistance to wealthy people, and postponing certain taxes in places where people in need are present.

\section{Keywords}

Ottoman State, Benghazi, Drought, Food Shortage, Forced Emigration, Aids. 


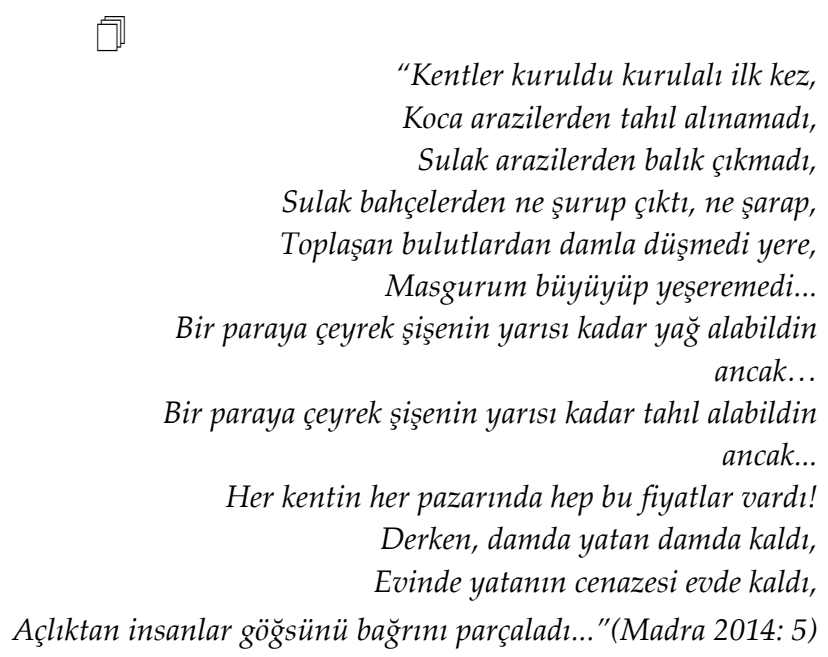

\section{GİRIŞ}

İnsanlar, dünya üzerinde farklı coğrafi mekânlarda yaşamışlardır. Bu coğrafi mekânlar, her yerde aynı özellikleri göstermemiş ve her yerde aynı cömertlik veya cimrilik içinde de olmamıştır (Kılıç, 2002, s. 728). Nitekim farklı özellikler arz eden coğrafyalarda tarih boyunca görülen kıtlıklar, depremler, yangınlar, çekirge istilaları, şiddetli yağmurlar ve kışlar, insan hayatını ciddi şekilde tehdit etmiştir. Sosyal, çevresel ve ekonomik olarak önemli zararlar ortaya çıkarmıştır. Bu zararları ortaya çıaran afetlerden bir tanesi de uzun süren kuraklıklar olmuştur.

Doğal bir iklim olayı olan kuraklık, yağışların bir bölgede beklenenden daha az olması durumudur. Dolayısıyla sadece sürekli az yağış olan bölgelerde değil, yağışlı bölgelerde de kurak dönemler olmuştur. Kuraklıktan söz edilmesi için yağışların normal ya da beklenen düzeyin altında olduğu zamanın en az bir mevsim veya bir yıl sürmesi gerekir. Dolayısıyla kuraklık belli bir bölgede, yağışların belli bir süre boyunca normalden az olmasıyla ortaya çıkmaktadır (Şahin ve Kurnaz, 2014, s. 13). Herhangi bir zamanda herhangi bir yerde meydana gelebilmektedir. Birçok araştırmacıya göre, sayılan otuz bir kadar doğal afet içerisinde en etkili olanı kuraklıktır (Kadığlu, 2011, s. 17-24). Etkisi altına aldığı coğrafi alanın boyutuna göre tesiri büyük, orta veya küçük ölçeklerde olabilmektedir (Ülgener, 1984, s. 45-48).

Kuraklık, en kapsamlı sosyo-ekonomik zararlara neden olan, yavaş gelişen, en sinsi ve en tehlikeli doğal afet olarak da kabul edilmektedir. Suyun çoğu yani sel nasıl ölümcül ise suyun azı yani kuraklık da ölümcüldür. Kuraklık, deprem gibi çeşitli büyüklüklerde oluşabilen doğal bir afettir. Kuraklığın çevreye ve sosyal hayata önemli etkileri vardır. Çevreye etkileri, topraktaki su ve suyun kalitesine zarar verir, bitki alanları daralır, hayvanların doğal hayatlarına nüfuz eder. Sosyal hayata ilişkin etkileri arasında yiyecek kıtlı̆̆l, buna bağlı olarak fakirleşmede artış ve devamında da göç söz konusu olmaktadır (Tekin, 2015, s. 330).

Kuraklık, dünyanın birçok yerinde olduğu gibi (Erler, 2012, s. 23) değişik zamanlarda Osmanlı Devleti'nde de görülmüştür. Nitekim Osmanlı Devleti, çok çeşitli iklim ve arazi şartlarına sahip topraklara hâkim olmuştur (Coşgel, 2007, s. 167). Anadolu'nun önemli bir kısminda Akdeniz iklimi ya da karasal iklimin etkili olması nedeniyle kuraklık vakaları periyodik olarak yaşanmıştır. Yine Balkanlar'da da özellikle yaz döneminde kuraklıkların görüldüğü Akdeniz iklimi ile karasal iklim hâkimdir. Mısır's da kapsayan Orta Doğu bölgesinde ise kuraklık vakalarının daha yaygın ve etkili olduğu karasal iklim ve çöl iklimleri 
görülmektedir. Dolayısıyla Osmanlı coğrafyası geneli itibarıyla özellikle yaz aylarında görülmek üzere kronik kuraklıklara yabancı değildir (Karademir, 2014, s. 45). ${ }^{1}$

Yukarıda da değinildiği üzere kuraklığın sosyal hayata ilişkin çeşitli etkileri vardır. Bunlardan bir tanesi de kıtlıktır. Genel olarak kıtlık, "ilerlemiş düzeyde yaygın açlık hali" (Hionidou, 2002, s. 65) olarak ifade edilmektedir. Birkaç özel tanıma yer verilecek olursa kıtlık, "açlık veya açlıktan kaynaklanan hastalıklardan ölümlerin gerçekleştiği geniş kapsaml besin yoksunluğu" (Gráda, 2007, s. 5) diye de tanımlanabilmektedir. Yine, "açlık ve buna bă̆lı hastalıklara sebebiyet veren ve gıda üretiminde ya da dağıtımındaki yetersizliğe neden olan "arz krizi"ne" (Cox, 1981, s. 5) de kıtlık denilmektedir. Türk Dil Kurumu Sözlüğü'nde ise kıtllk için; "kuraklı, savaş vb. nedenlerle ürünün yetişmemesi ve bundan doğan açlık"2 tanımına yer verilmiştir.

Kıtlıkların doğal şartlara bağlı olarak ne zaman, nerede ve hangi şartlarda ortaya çıkacağ önceden bilinemediği ve ölümcül neticeler verdiği için aynı zamanda bir afet olarak değerlendirilmektedir (Kılıç, 2002, s. 718). Bu afetin ortaya çımasında sel, yangın, kuraklık, deprem, çekirge istilası, salgın hastalıklar, aşırı soğuk ve sıcaklıklar gibi çoğunlukla doğal sebepler etkili olmakla birlikte eşkıyalık olayları, isyanlar ve harpler gibi beşeri kaynaklı sebepler de etkili olabilmektedir (Erler, 2002, s. 762-771). Doğal sebeplerle ortaya çıkan sorunların şiddeti, beşeri nedenlerle oluşanlara nispeten daha yüksektir. Yine doğal sebeplerle meydana gelen kıtlıkların etkisi hızlı olmakta ve refah içinde yaşayan bir toplumu birdenbire kıtlığın pençesine düşürebilmektedir. Nitekim yaşanan ağır bir sel felaketi ya da çekirge istilası koca kentleri bir anda perişan edebilmektedir. Bundan başka birkaç yıl süren kuraklık sonucunda tarımsal üretimde yaşanan sıkıntı büyük bir ülkeyi yıllar süren kıtlıklarla baş başa bırakabilmektedir (Karademir, 2014, s. 14). Kitlıkların etkileri yalnızca meydana geldikleri dönemlerle de sınırlı kalmamaktadır. Bunların ortaya çıkardığı sosyal ve iktisadi meseleler, toplumları ve devletleri uzun süre meşgul edebilmektedir. Çünkü büyük sıkıntılara yol açan bir kıtlık olayından etkilenen insanların düzenli hayata geçişleri uzun zaman almaktadır (Kılıç, 2002, s. 718).

Osmanlı Devleti'nin bazı bölgelerinde farklı dönemlerde kıtlık olaylarıyla karşılaşılmıştır. XVI. yüzyıldan XIX. yüzyılın sonlarına kadar Anadolu, Balkanlar, Kırım, Kuzey Afrika, Suriye ve Kıbrıs'ın birçok yerinde kıtlık hadiseleri yaşanmıştır. ${ }^{3}$ Söz konusu kıtlıklar, dönemi itibariyle Osmanlı Devleti'ni birçok yönden olumsuz etkilemiştir. Örneğin Karadeniz bölgesinde 1494'ten 1503 yılına kadar geçen dokuz yıllık süre içinde meydana gelen büyük bir kıtlık ve veba ülkeyi kırıp geçirmiştir. Kıtlık öylesine ciddi bir hal almıştır ki 1 akçe karşılığında ve çok büyük sıkıntılarla ancak 50-60 dirhem (yaklaşık 150-180 gram) ağırlığında bir ekmek alınabilmiştir. Bu olay esnasında, Bolu taraflarında iki aydan fazla bir süre ekmek bulunamaz olmuş ve insanların "ot otladıkları" görülmüştür (Demirtaş, 2004, s. 38).

Kuraklığın etkisinin üç yıl gibi çok uzun bir süre devam ettiği dönemlerde çiftçilerin mağduriyeti daha da artmıştır. Nitekim toprağa bağımlı bir hayat süren köylüler, kuraklığın etkili olduğu dönemde bunun etkisini azaltmanın çaresini bulma arayışı içinde olmuşlardır (Özdeğer, 2008, s. 88). Fakat bu konuda herhangi bir çare bulamayınca bulundukları bölgeyi terk etmek zorunda kalmışlardır. Örneğin; 1559-1560 yıllarında Karadeniz'in kuzey kesimindeki Osmanlı topraklarında şiddetli bir kıtlık meydana gelmiştir. Bu esnada kıtlıktan kurtulmak isteyen Kırım Tatarları ve Nogaylar arasında göç hareketleri baş göstermiştir. Fakat bu hareketlilik bölgede büyük bir kargaşaya da yol açmıştır. Reayaya ait araziler ve sürüler

Bölgelerin iklim özellikleri ve yaşanan kuraklıklarla ilgili olarak ayrıca bkz. (Atalay, 2011); (Gökhan, 1998).

İlgili madde için bkz. (Türk Dil Kurumu Sözlüğü, "Kıtlık”, https://sozluk.gov.tr/?kelime=, Erişim Tarihi: 23 Ekim 2019).

3 Osmanlı Devleti'nde XVI. yüzyıl ve sonrasında görülen kıtlık olayları için bkz. (Karademir, 2014, s. 11-40); (Bayar, 2013); (Erler, 2012); (Tekin, 2015, s. 329-341). 
zarar görmüştür. ${ }^{4}$ Aynı zamanda toprakla uğraşan köylünün, başka bölgelere göç etmek zorunda kalması, birçok arazinin boş kalmasına ve tarımsal faaliyetlerin kesintiye uğramasına neden olurken devletin de önemli oranda vergi kaybına uğramasına yol açmıştır (Erler, 2002, s. 768-769). Bütün bunlara karşılık Osmanlı Devleti ise, sosyal devlet anlayışının bir gereği olarak kısa, orta ve uzun vadeli çözüm yolları üretmeye çalışmıştır (Asan, 2018, s. 4).

Yaşanan kıtlık hadiseleri dönemin şairlerinin eserlerine de konu olmuştur. Nitekim klasik dönemde meydana gelen arpa kıtlıklarına dair Necatî (Ö. 1509) ile Hayretî (Ö. 1534-35)'nin yazdığı kasideler bu alanda yazılmış eserlere örnek olarak verilebilir. İki divan şairi de eserlerinde, bir ara yaşamış oldukları arpa kıtlığının kendileri ve toplum üzerindeki olumsuz etkisini ifade etmeye çalışmıştır. Örneğin Necatî, "Kasîde-i Arpa" başlıklı şiirinde, kıtlık yüzünden yaşadığı kişisel sıkıntıların yanı sıra o esnada değişen arz talep dengesi yüzünden arpanın çok fazla değer kazanmasını ve bunun neticesinde halkın büyük bir geçim sıkıntısına düşmesini şöyle dillendirmiştir (Çetinkaya, 2009, s. 49-50):

"Kanı ol yâr-i mihribân arpa

Sayruya sihhat ata can arpa"5

"Kalmadı faka takıcak buğday

Ilde olalıdan giren arpa"6

"Kalmadı at u don $u$ hem harçluk

Eyledi halka çak ziyan arpa"7

Osmanlı arşiv belgelerine bakıldığında kıtlık anlamda "kaht" iُ kelimesi kullanılmıştır. Kaht; kıtlı, kuraklik; kuraklıktan dolayı mahsulün yetişememesi (Devellioğlu, 2007, s. 482) veya kuraklığa bağhl mahsul kıtlı̆̆ı ve açlık (Sami, 1318, s. 1057) manasına gelmektedir. Nitekim çalışma dâhilinde incelenen arşiv belgelerinde de ortaya çıkan hadise, daha çok kaht veya "kaht u galâ" نط şeklinde belirtilmiştir. "Kaht u galâ" şeklinde belirtilmesi ise, sadece kuraklığın değil aynı zamanda pahalılı̆ $ı n^{9}$ da etkili olduğunu göstermektedir. Bu hadiseden zarar gören ahali için de, "kıtlı̆̆a uğramış, aç kalmış" (Devellioğlu, 2007, s. 482) anlamında, "kahtzedegân"10

4 Silistre Sancakbeyi, bu durumla ilgili olarak merkeze şu bilgileri vermiştir: “Söz konusu topluluk kısmen Nogaylardan, kısmen Kırım Tatarlarından oluşuyor, göç üç aydır sürüyor. Ne başları var, ne silahları, zavallı yoksullar... çoğu kıtllk yüzünden ailesiyle birlikte yayan gelmiş, yiyecek bulmak için ülkeye dayanmış..." Bkz. (Veinstein, 2001, s. 298).

Boğdan Voyvodası Alexandru Lapuşneanu'dan gelen bilgi ise şu şekildedir: "Tatar Nogaylar, büyük kıtlık çıkınca Kırım tarafına kaçmışlar. Ama Kırımlılar da kıtlık çektiği için, Tatar Nogaylar daha uzağa gitmişler, steplerde avladıklarıyla karınlarını doyurarak, Kili (Kilija), Akkerman ve Bender kalelerine varmışlar. Kimileri steplere yerleşmiş, kimileri de Boğdan sınırına kadar yollarına devam etmişler. Sınırı aştılar, şimdi de reayanın sürülerine zarar veriyorlar." Bkz. (Veinstein, 2001, s. 299).

5 O şefkatli, sevgi dolu, sevgiliye benzeyen, hastaya sağlık, ata can olan arpa nerede?

6 Şehirde arpa çok pahalandığından beri kapana takacak buğday kalmadı.

7 At, giyecek ve harçlık kalmadı. Arpa kıtlığı halkı tamamen kayba uğrattı.

8 "kaht" ve "kaht u galâ" ibarelerinin yer aldığı birkaç belge örneği vermek yerinde olacaktır. Örneğin bir belgede; "Bu sene devam eden kuraklıktan dolayı hasılat mahv olarak kaht u galâ derecesinde olup..." şeklinde ibare yer almıştır. Bkz. (BOA, İ. ML, 1/9: 2-1). Başka bir belgede; "Bingazi'de meydana gelen kuraklık kaht u galâ derecesine varmış..." şeklinde ibare yer almıştır. Bkz. (BOA, BEO, 107/7956). Son olarak 20 Kasım 1892 tarihli belgede de; “Bingazi taraflarında kaht u galâ zuhur eylediği alınan haberlerden anlaşılmış..." şeklinde ibareye yer verilmiştir. Bkz. (BOA, BEO, 110/8220).

${ }^{9}$ Devellioğlu da Osmanlıca-Türkçe Ansiklopedik Lûgat'ta, "kaht u galâ" için "kıtlık ve pahalılık" olarak tanımlama yapmıştır. Bkz. (Devellioğlu, 2007, s. 482). Nitekim Bingazi'de de kıtlık ve pahalılığın etkili olduğu arşiv belgelerinde görülmektedir. Burada bir örnek verilecek olursa, 10 Ocak 1893 tarihli bir belgede, Bingazi'de meydana gelen kitlk ve pahalılı nedeniyle zahire ihtiyacının olduğu belirtilmiştir. Bkz. (BOA, İ. DH., 1301/29).

10 "Kahtzedegân" ibaresinin yer aldığı arşiv belgesi örnekleri için bkz. (BOA, BEO, 82/6103); (BOA, BEO, 105/7820); (BOA, BEO, 149/11152). 
تحند-is

ibaresi kullanılmıştır. Bu çalışmada ise, XIX. yüzyılın sonunda Bingazi'de meydana gelen kuraklık ve akabinde ortaya çıkan kıtlık ve zorunlu göç hadisesi incelenmektedir.

\section{Bingazi'de Meydana Gelen Kuraklık ve Kıtlık \\ 1.1. Bingazi}

Bingazi, Akdeniz ile Sahra-yı Kebir arasında "Berka" olarak adlandırılan bölgede yer alan aynı isimli sancağın merkezidir (Tevfik, 1318, s. 473-474). Bölgenin ikinci kalabalık şehri olup aynı zamanda doğu kıyılarının en büyük limanına sahiptir (Erinç, 1992, s. 181-182). 1551 Trablusgarp seferi sırasında "Berka" bölgesinin Osmanlı hâkimiyetine girmesinden (Rossi, 1979, s. 447) sonra Bingazi de 1578 'de kesin olarak Osmanlı topraklarına katılmıştır. Bu tarihten itibaren Garp Ocakları'nda Trablusgarp Eyaleti'nin bir sancağı olan Bingazi, XVII. yüzyılda Dayı'ların, XVIII. yüzyılda da Karamanlı Ailesi'nin idaresinde kalmıştır. Daha sonra bir dönem Trablusgarp Vilayeti'ne bağlı sancak, bir dönem müstakil bir vilayet olan Bingazi, en son 1888'de doğrudan İstanbul'a bağlı müstakil bir mutasarrıflık haline getirilmiştir (Gehedr, 1996, s. 180).

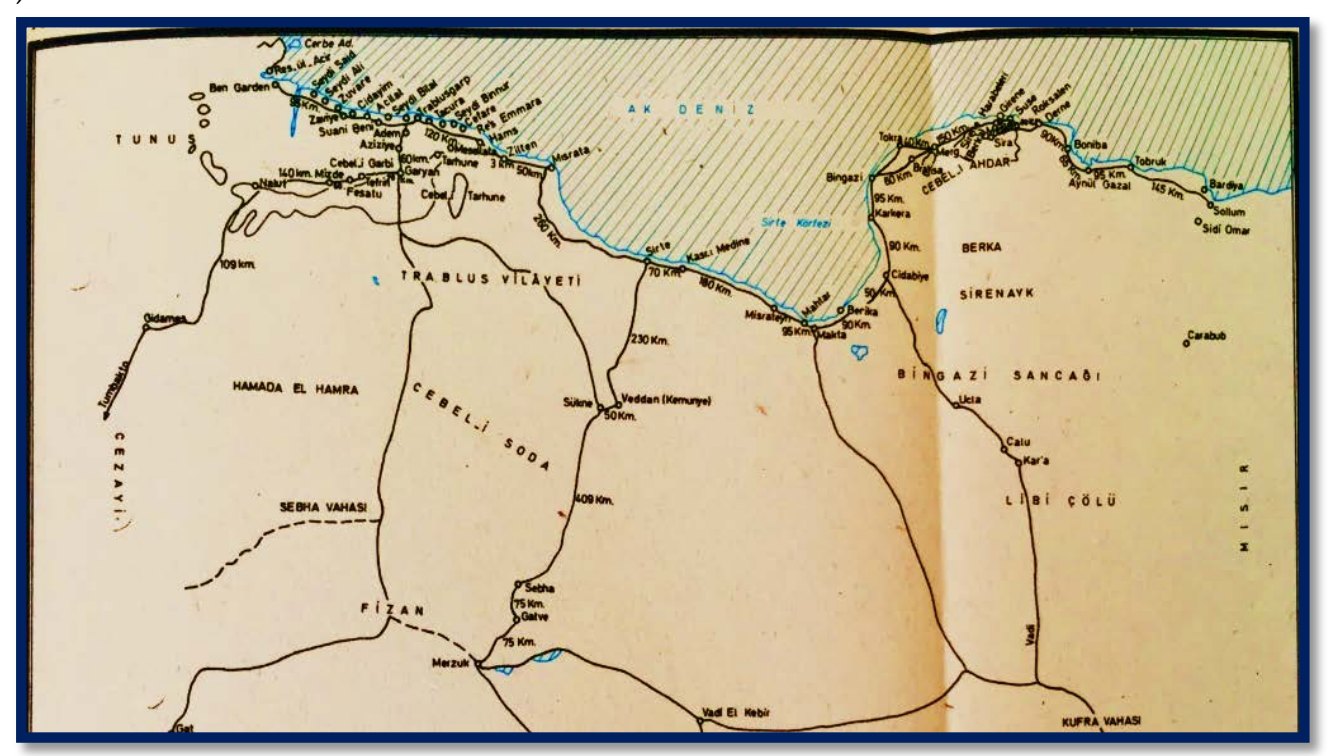

Harita 1: Trablusgarp Vilayeti ve Bingazi Sancă̆ (1911-1912 Osmanl-İtalya Harbi ve Kolă̆ası Mustafa Kemal, 1985), Ekler; Harita: 2)

Bingazi'nin kuzeyinde Akdeniz, doğusunda Mısır, batısında Trablusgarp Vilayeti ve güneyinde Libi Çölü bulunmaktadır ( Ali Subhi, 1307, s. 58). Denizden yüksekliği 900 ilâ 1000 metre kadardır. Arazisi, bir çeşit kırmızı toprak ile örtülüdür (Ali ve Ahmed Nuri 1301: 112). Bölgedeki başlıca geçim kaynağı ise tarımdır (Erinç, 1992, s. 181-182). Bulunduğu coğrafya itibariyle sıcak ve karasal bir iklime sahiptir. Ortalama sıcaklık 21,5 derece olmakla birlikte bazı dönemlerde sıcaklığın 40 dereceyi geçtiği görülmektedir (Mehmed Nuri ve Mahmud Naci, 2012, s. 43-45). Dolayısıyla yağmurun az yağdığı dönemlerde su sorunu ile karşılaşılması kaçınılmaz olmakta, bu da kuraklık yaşanmasına sebebiyet vermektedir. Bu sorun, özellikle başlıca geçim kaynağının tarıma dayandığı bölgede zaman zaman kıtlıkların da yaşanmasına yol açmıştır.

\section{Bingazi'de Meydana Gelen Kuraklık ve Kitlık}

Bingazi, bulunduğu coğrafya ve iklim şartları itibariyle farklı tarihlerde şiddetli kuraklık 
hadiselerine maruz kalmıştır. Nitekim bölgede 1887 (BOA, DH. MKT, 1414/75; BOA, DH. MKT, 1423/26), 1892-1893, 1905-1906 (BOA, DH. ŞFR, 392/124; BOA, DH. ŞFR, 395/62), 1907-1908 (BOA, DH. MKT, 2614/68; BOA, BEO, 3277/245706; BOA, BEO, 3416/256134) yıllarında etkili kuraklık vakalarının yaşandığ 1 tespit edilmiştir. $\mathrm{Bu}$ tarihlerde yaşanan kuraklık nedeniyle özellikle zahire kıtlığının ortaya çıktı̆̆ı ve bunu gidermeye yönelik de birtakım tedbirler alındığı görülmüştür. Örneğin 1887 yılında, Bingazi'de meydana gelen kuraklık sebebiyle zahire sıkıntısının yaşandığı (BOA, DH. MKT, 1414/75) bildirilmiştir. 1906 yılında, yine kuraklık sebebiyle Bingazi'den zahire ihracinın yasaklanması (BOA, DH. ŞFR, 392/124) yoluna gidilmiştir. 1908 yılında ise, Bingazi havalisindeki kuraklığın kaht yani kıtlık derecesinde olduğu ve gerekli tedbirlerin biran önce alınması (BOA, BEO, 3416/256134) istenmiştir. Nitekim bu yılda Bingazi'de kuraklıktan etkilenenlere, Ziraat Bankası'nca kredi verilmesinde kolaylık sağlanması (BOA, DH. MKT, 2614/68) talep edilmiştir. 1910 yılına gelindiğinde ise Meclis-i Mebusan'da söz alan bölgenin milletvekilleri, Bingazi'de on yılda bir yağmur yağdığııı ve dört yıldan beri kıtlı̆̆ın ortalığı kasıp kavurduğunu (Koloğlu, 2001, s. 55) dile getirmişlerdir.

Aynı coğrafyada bulunan Trablusgarp Vilayeti'nde de şiddetli kuraklık olaylarının yaşandığı görülmektedir. Nitekim Trablusgarp Vilayeti milletvekillerinden Mahmut Naci, Mustafa, Sadık ve Ferhat beylerin ifadelerine göre 1907-1910 yılları arasında vilayet dâhilinde hiç yağış görülmemiştir. Bu nedenle de kuraklık meydana gelmiştir. ${ }^{11}$ Mahmut Naci Bey'in 20 Haziran 1910 tarihli oturumdaki ifadesine göre kuraklık, tarımla uğraşan halkı oldukça zor durumda bırakmıştır. Kuraklığın ortaya çıkardığı kıtlık, açlık ve tifo hastalığı gibi nedenlerden dolayı nüfusun $\% 30$ 'u vefat etmiştir. Yine bölge halkının \%20'si, iaşelerini temin etmek maksadıyla Cezayir, Tunus ve Mısır'a göç etmiştir. ${ }^{12} 1911$ yılına gelindiğinde, yine Trablusgarp milletvekillerinden Mahmut Naci ve Sadık beylerin belirttiklerine göre, 200 bine yakın kişi iaşelerini temin etmek maksadıyla Tunus ve diğer çevrelere göç etmiştir. Yine kırsalda yaşayan 4 bin kişi de bu durumlardan dolayı bulundukları yerleri terk ederek merkeze göç etmişlerdir. Merkeze göç sonrası 1911 yılı Mart-Haziran ayları arasında 514 kişinin açlıktan öldüğü bildirilmiştir. ${ }^{13}$ Dolayısıyla bölgede 3-4 yıl devam eden kuraklık süresince halk zor duruma düşmüş, hayvanları telef olmuş ve kendileri de göç etmek zorunda kalmıştır. Osmanlı Hükümeti ise bu sıkıntıların görüldügü dönemde Trablusgarp halkına yardım göndermeye çalışmıştır.

Çalışma konusu dâhilinde olan Bingazi'de 1892-1893 yıllarında meydana gelen kuraklık hadisesine bakıldığında, bölgede fazlasıyla etkili olduğu görülmektedir. Nitekim Bingazi Mutasarrıfı Mehmed Reşid Paşa tarafından gönderilen 30 Temmuz 1892 tarihli yazıda, ortaya çıkan kuraklıktan dolayı hasılatın mahvolduğu, kuraklığın kıtlık derecesine ulaştığı ifade edilmiştir. Nitekim bu durum ahali ve urbanı (yerli Arap aşiretleri) da perişan bir halde bırakmıştır. Hatta bazıları, yemeklik ve tohumluk zahirenin yetersiz kalmasından dolayı, iaşelerini temin etmek için çevre vilayetlere göç etmeye başlamıştır. Geride kalanlar içerisinde kıtlık nedeniyle telef olanlar olmuştur. Dolayısıyla muhtaç durumda olan ahalinin hayatlarını devam ettirmeleri ve ertesi yıl zirai faaliyetlerini sürdürebilmeleri için tohumluk ve yemeklik olmak üzere 30 bin kile buğday ve 120 bin kile arpanın ziraat mevsiminden önce

11 İfadeleri için bkz. (Meclis-i Mebusan Zabıt Ceridesi, 37. İn'ikâd, Devre 1, Cilt 2, İçtimai Sene: 2, 26 Kânunusani 1325/8 Şubat 1910 Salı Oturumu, s. 208-209).

12 Bu oturumdaki görüşmelerde ihtiyaçların giderilmesi için 7 bin Lira talep edilmiştir. Bkz. (Meclis-i Mebusan Zabıt Ceridesi, 118. İn'ikâd, Devre 1, Cilt 6, İçtimai Sene 2, 7 Haziran 1326/20 Haziran 1910 Pazartesi Oturumu, s. 430).

13 Mahmut Naci ve Sadık beylerin ifadeleri için bkz. (Meclis-i Mebusan Zabıt Ceridesi, 5. İn'ikâd, Devre 1, Cilt 1, İçtimai Sene 4, 10 Teşrinievvel 1327/23 Ekim 1911 Pazartesi Oturumu, s. 68). 
yetiştirilmesine ihtiyaç duyulmaktaydı. Bunun da İstanbul'dan veya civar vilayetlerden temin edilmesi talep edilmiştir (BOA, İ. ML, 1/9: 2-1).

Sıhhiye Nazırı tarafından Saderet'e gönderilen 20 Kasım 1892 tarihli telgrafta, Bingazi taraflarında kaht $u$ galâ'nın ortaya çıtığının haber alındığı bildirilmiştir. Nazırın belirttiğine göre, 1287/1870-1871 senesi ile bundan önce de bir defa daha Bingazi'de kaht u galâ ortaya çıkmıştır. Hatta bunu müteakiben veba illetiyle de karşı karşıya kalınmıştır. Dolayısıyla bir kez daha büyük bir illetin ortaya çıkmasından endişe duyulduğu ifade edilmiştir. Bunun önüne geçilmesi adına biran önce hükümet nezdinde gerekli görüşmelerde bulunularak bu sorunun giderilmesi istenmiştir (BOA, BEO, 110/8220). 24 Aralık 1892 tarihinde kaleme alınan bir iradede ise, Bingazi'de etkili olan kuraklık ve kıtlı̆̆ın giderilmesi ve memalik-i şahanenin en zengin kıtası derecesine erişmek kabiliyetine sahip bulunan bu memleketin, zirai ve ticari açıdan ilerlemesi için gerekli tedbirlerin alınmasına ve bölgenin ıslah ve imarına çalışılmasına vurgu yapılmıştır (BOA, İ. HUS, 7/16).

\subsection{Osmanlı Devleti'nin Aldığı Tedbirler ve Yapılan Yardımlar}

Orhan Gazi zamanından başlayarak yerleşik bir toplum düzeni ve gittikçe gelişen bir idarî ve askerî düzen üzerine oturmaya başlayan Osmanlılarda tarım ağırlıklı bir iktisadî düzen hâkim olmuştur (Öz, 1999, s. 66). Tarım ekonomisinin ana ürünleri ise buğday ve arpadır. Büyük kitlelerin geçimi, geçimlik ekonomi, ordunun ve şehirlerin iaşesi hububat ekimine, özellikle de buğday ve arpa ekimine dayanmıştır. Hububat ekimindeki yetersizlik darlık ve açlığa yol açacağından devlet, tarla ziraatını, hububat ekimini kontrol altında tutma zorunluluğu duymuştur. Dolayısıyla Osmanlı Devleti'nin ekonomik düzeninde bu kadar önemli bir yere sahip olan hububat üretiminde yaşanacak kıtlıklar da toplumda ekonomik ve sosyal hayat açısından büyük önem taşımıştır (İnalcık, 1990, s. 1-2).

XIX. yüzyılın son çeyreği, Osmanlı Devleti'nde siyasi, sosyal, idari ve askerî alanda yeni gelişmelerin yaşandığı bir dönemdir. Nitekim “93 Harbi" diye adlandırılan 1877-1878 Osmanl1Rus savaşı meydana gelmiş ve Osmanlı açısından büyük bir mağlubiyetle sonuçlanmıştır. Kırım Savaşı'yla birlikte, 1854 'te dış borçlanma süreci başlamış ve bu süreç hızla ilerlemiştir. Borçlar ödenemeyince alacaklı devletler ile Osmanlı Devleti arasında yapılan görüşmeler sonucunda Duyun-u Umumiye İdaresi kurulmuştur. Ülke genelinde teşkilatlanan Duyun-u Umumiye İdaresi, büyük boyutlara ulaşan Osmanlı borçlarının Avrupalı alacaklılara geri ödenmesini denetlemek üzere kurulmuştur. Siyasi alanda ise, 1876 yılında Meşrutiyet ve Kanun-ı Esasi ilan edilmiş, anayasal bir rejime geçilmiştir. ${ }^{14}$ Kısacası Osmanlı Devleti, bir taraftan söz konusu gelişmelere uyum sağlamaya çabalarken diğer taraftan kıtlık hadiseleriyle mücadele etmek durumunda kalmıştır. Kıtlık dönemlerinde ve özellikle kıtlığın etkili olduğu bölgelerde müdahaleci bir politika izlemiştir. Söz konusu bu politika, kıtlı̆̆a maruz kalan ahaliyi koruma güdüsünden kaynaklanmıştır (Asan, 2018, s. 10).

Bingazi'de, 1892'de devam eden kuraklıktan dolayı hasılat mahvolmuş ve durum kıtlık hadisesine dönüşmüştür. Bingazi'deki ahali ve urban öteye beriye dağılmaya başlamıştır. Bunun üzerine Bingazi idaresi, muhtaç durumda olan ahalinin tohumluk ve yemeklik ihtiyacını karşılamak üzere, tavizen (karşıllğı alınmak üzere) 30 bin kile buğday ile 120 bin kile arpayı merkezi yönetimden talep etmiştir. Konuyla ilgili olarak Meclis-i Mahsûs-ı Vükelâ'da yapılan görüşmede, talebin ehemmiyeti kabul edilmiş ve istenilen zahirenin gönderilmesi zaruri görülmüştür (BOA, BEO, 47/3495; BOA, İ. ML, 1/9: 3-1). Bu anlamda, ilk etapta ihtiyac1 karşılamak üzere tavizen 7.500 kile buğday ile 20 bin kile arpanın maliye hazinesi tarafından hemen satın alınarak en erken gidecek posta vapuruna yüklenmesi ve bölgeye gönderilmesi

14 Yaşanan bu siyasi, askeri ve ekonomik gelişmeler için bkz. (Armaoğlu, 2006); (Karal, 2011); (Shaw ve Kural Shaw, 2010). 
planlanmıştır. Aynı zamanda hem belirlenin zahirenin bölgeye ulaşmasını sağlamak hem de bölgedeki ihtiyacı tespit etmek üzere bir memurun da tayin edilmesi istenmiştir (BOA, İ. ML, 1/9: 3-1). Nitekim bu hususlar hakkında gereğinin yapılması padişah tarafından da irade olunmuştur (BOA, BEO, 47/3495).

Bingazi kahtzedegânının yemeklik ve tohumluk ihtiyaçları için Konya Vilayeti'nden temin edilen zahirenin Silifke'nin Taşucu İskelesi'ne indirilerek buradan gönderilmesi ve nakliyatta da İdare-i Mahsusa'nın Kayseri Vapuru'nun kullanılması planlanmıştır. Fakat daha önce yapılan bu bilgilendirmeye rağmen ilgili vapur, iki gün önce iskeleye gelmiş ve içerisinde tüccar malı olduğu için deposunda yer olmadığını beyan ederek zahireyi almadan gitmiştir (BOA, DH. MKT, 2007/116). Bunun üzerine 7.500 kile buğday ile 10 bin kile arpanın nakli için 45 güne kadar geleceği haber alınan Ali Saib Paşa Vapuru'nun kullanılması planlanmıştır. Bu sefer, ilgili vapur süvarisinin başka iskelelerden tüccar malı almayıp ambarlarında zahireyi taşıyacak yer bulundurması bildirilmiştir. Daha sonra vapurun, zahireyi İzmir'e ulaştırması ve burada Bingazi'ye gidecek vapura aktarma yapması istenmiştir (BOA, BEO, 82/6103). Fakat zahirenin Ali Saib Paşa Vapuru ile İzmir'e gönderilerek aktarma yapılması hususu da mümkün olmamıştır. Bunun üzerine vapurun, Silifke İskelesi'ne uğrayıp çuval içindeki zahireyi İstanbul'a aktarma yapmak üzere hareket etmesi Suriye Sahil Başacenteliği'ne haber verilmiştir. İlgili vapur İstanbul'a ulaştığında da zahirenin Bingazi'ye gidecek vapura nakledilmesi ve bundan doğacak masrafın peşin olarak ödenmesi mahalline bildirilmiştir (BOA, BEO, 84/6299).

Bingazi'de meydana gelen kuraklığın kaht u galâ, yani kıtlık derecesine varması ve ahalinin elindeki yemeklik ve tohumluk zahirenin ihtiyaca yetersiz kalması üzerine Konya Vilayeti'nden 7.500 kile buğday ve 15 bin kile arpa tertip edilerek sevkiyata başlanmıştır (BOA, BEO, 107/7956). Nitekim bir gün sonra, Konya vilayetinden istenilen 7.500 kile buğday ve 15 bin kile arpanın vapura yüklenerek sevk edildiği haber verilmiştir (BOA, BEO, 107/7956).

24 Kasım 1892 tarihinde Dâhiliye Nazırı tarafından verilen bilgiye göre, 7.500 kile buğday ile 11.500 kile arpa, Ali Saib Paşa Vapuru ile Silifke'nin Taşucu İskelesi'nden; 3.500 küsur kile arpa da Tarsus Vapuru ile İzmir'den sevk edilmiştir. Böylece istenilen zahirenin tertip edildiği ve bundan başka gönderilecek bir şey kalmadığı; ancak Dinar Şimendifer mevkiinde müzayede ve ihale olunandan başka 15 bin kile buğday ve 6 bin kile arpanın mevcut olduğu ve eğer bunlar Bingazi'ye gönderilecek ise derhal İzmir'e nakledilebileceği Konya Vilayeti'nden bildirilmiştir. Diğer taraftan, Bingazi'den 30 bin kile buğday ile 120 bin kile arpa daha istenilmekte olduğuna nazaran bu miktarın gönderilmesinin de yeterli olmayacağ 1 ve ilerde yine zahire istenileceği anlaşılmıştır. Nitekim daha önce Bingazi'ye 300 bin kıyye un gönderildi ise de bununla da ihtiyacın giderilemediği görülmüş ve tohumluk ve yemeklik için daha hayli zahire istenileceği anlaşılmıştır. Dolayısıyla Konya'nın yakın mahallerinde gerek mevcut bulunan ve gerekse satın alınan zahirenin elden çıarılmaması için Maliye Nezareti'ne emir verilmesi talep edilmiştir (BOA, İ. ML, 3/37).

Bu konuyla ilgili olarak Meclis-i Mahsûs-1 Vükelâ'da alınan kararda, bölgeye gönderilen 7.500 kile buğday ve 15 bin kile arpayla şimdilik idare edilebileceği, daha fazla zahire gönderilmesine gerek olmadığı bildirilmiştir. Trablusgarp ve Bingazi'deki asâkir-i şahane için gerekli olan un, arpa, yağ ve pirincin de zaten Hazine'den her hafta verilmekte olan 120 bin kuruş ile Bâb-ı Vâlâ-yı Seraskeriye'ce satın alınarak sevk edilmekte olduğu ve dolayısıyla Bingazi'deki zahire ihtiyacının yalnız ahaliyi ilgilendirdiği vurgulanmıştır. Ayrıca Bingazi Mutasarrıflığı'ndan talep edilen zahire pek fazla görülmüş olmakla birlikte eğer gönderilen zahireden sonra tekrar ihtiyaç söz konusu olursa yine Konya Vilayeti'nce tertip edilebileceği ve mahalline gönderilebileceği maliye nazırınca bildirilmiştir (BOA, DH. MKT, 2024/93). 
Bingazi'deki ihtiyaç sahibi ahali için Padişah tarafından da 10 bin Lira ihsan buyrulmuştur. Bu parayla da zahire satın alınmış ve bölgeye gönderilmiştir. Fakat bu zahirenin ihtiyaca yeterli gelmediği mutasarrıflıktan bildirilmiştir. Bunun üzerine bölgedeki kahtzedegân için daha evvel olduğu gibi İane Komisyonu teşkil edilmesi ve iane biletleri basılması çare olarak düşünülmüştür (BOA, BEO, 102/7578). Fakat bu işlemlerin de uzun süreceği anlaşılmış ve daha önce tertip edilen Hicaz İanesi (İane-i Hicaziye)'den elde kalan 2.800 Lira ile İstanbul'da üçüncü derecede un satın alınarak hemen Bingazi'ye sevk edilmesi kararlaştırılmıştır. Kuraklığın derecesini tahkik etmek ve gönderilecek unun dağıtımına nezaret etmek üzere de bir memurun bölgeye gönderilmesi Dâhiliye Nezareti'ne bildirilmiştir. Ayrıca Hicaz İanesi için tertip edilip daha sonra vilayetlere gönderilen biletler bedelinden bir kısmının da henüz ödenmemiş olduğu görülmüştür. Dolayısıyla bu biletler bedelinden tahsil edilecek paranın da Bingazi kahtzedegânı için alınacak zahireye ayrılması Meclis-i Mahsûs-ı Vükelâ kararıyla bildirilmiş ve bu hususta padişah tarafından da irade buyrulmuştur. İhtiyaç sahipleri için padişah tarafından ayrıca ihsan buyrulan 500 Lira'nın da Dâhiliye Nezareti veznesine ödenmesi hususunda Maliye Nezareti'ne malumat verilmiştir (BOA, BEO, 105/7820).

Trablusgarp ve Bingazi çevresinde ortaya çıkan kuraklık dolayısıyla Trablusgarp Vilayeti ile Bingazi Sancağı gelirlerinden 1892 yılında 6 milyon 500 küsur bin kuruş açık ortaya çıkmıştır. Bölge kumandanlığından bildirildiğine göre, Bingazi tarafında devam eden kuraklığa çekirge istilasının da eklenmesiyle ahali elindeki hayvanatı satmaya başlamıştır. Bu da bölgedeki Asâkir-i Şahâne idaresi ve iaşesi için gerekli olan hayvan ve bundan elde edilen etin tedarikinde sıkıntı yaşanmasına neden olmuştur. Dolayısıyla gerekli olan hayvan ve kavurma ile arpa ve samanın tedariki için 400 veya 500 bin kuruşun acilen gönderilmesi istenmiştir (BOA, BEO, 107/7956).

Bölgeden talep edilen paranın tedariki hususu merkezde görüşülmüştür. Bu konuda hazinece yapılan araştırmaya göre, Trablusgarp Vilayeti'nin H. 1308/M. 1890-1891 senesi gelirlerinin mahalli masraflara kâfi derecede olduğu ve Bingazi'de bulunan Asâkir-i Şahâne de dâhil olmak üzere Trablusgarp fırka-i askeriyesi için gerekli olan un ve sair ihtiyaçların zaten İstanbul'ca tedarik edildiği anlaşılmıştır. Ayrıca Selanik ve İşkodra'dan satın alınması gerekli görülen zahirenin de Selanik Vilayeti'nden tedarik edilmek üzere olduğu görülmüştür. Bingazi'deki 500 bin kuruş açık için de Manastır ve Yanya vilayetlerinden ilgili miktarda paranın tertip edildiği ve süratle mahalline yetiştirilmesi yönünde de maliyeye emir verildiği bildirilmiştir (BOA, BEO, 107/7956).

Bingazi kahtzedegânı için Gümülcine'nin yardımsever ahalisi tarafından da yardım sağlanmıştır. Nitekim bu yolda yapılacak un yardımının aktarma yoluyla İstanbul'dan gönderilmesi planlanmıştır (BOA, DH. MKT, 2031/40). Bununla ilgili olarak daha sonra Edirne Vilayeti'ne gönderilen yazıda, toplanan unun, Selanik'ten hareketle 28 Aralık 1892 Çarşamba günü Karaağaç İskelesi'ne gelecek olan Dolmabahçe Vapuru'na yüklenerek İstanbul'a gönderilmesi bildirilmiştir. Nitekim ilk etapta her biri ellişer kıyye olan 308 çuval un ilgili iskeleden vapura yüklenmiştir. Yine, İskeçe'de de 12.600 kıyye unun hazır edilerek ilgili iskeleye gönderilmek üzere olduğu mahallinden haber verilmesi üzerine, bunun da Selanik'ten gelecek vapura yüklenmesi istenmiştir (BOA, DH. MKT, 2038/60). Yine, 5 Şubat 1893 tarihinde, Bingazi kahtzedegânı için hazırlanıp İstanbul'a gönderilen 15 bin kıyye unun, Bingazi'ye gidecek ilk vapurla gönderileceği belirtilmiştir (BOA, DH. MKT, 2049/62).

Bingazi kahtzedegânı için Selanik'ten 360 bin kıyye un satın alınması kararlaştııılmıştır. Ortaya çıkacak masrafın da kıyyesi 36 paradan hesaplanarak, Selanik gelirlerinden karşılanması vilayet defterdarlığına yazılmıştır. Un bedelinin peşinen ya da Selanik Vilayeti ağnam gelirinden ödenmesinin uygun olacağı, aksi halde unun verilemeyeceğinin de haber verilmesi 
üzerine ihtiyaç duyulan unun geç kalmaması için belirten bedelin biran önce ödenmesi hususu Sadaret tarafından Maliye Nezareti'ne bildirilmiştir (BOA, DH. MKT, 9/11: 22).

1893 yılı ortalarında 360 bin kıyye un satın alınmış ve Bingazi kahtzedegânı için bölgeye gönderilmiştir. Fakat unlar, ambarlarda muhafaza edilmiş olmasına rağmen vaktinde kullanılmadığından bir süre sonra bozulmaya başlamıştır. Bu durumda ahalinin gelecek sene zahireye muhtaç kalacağı anlaşılmasından dolayı arpa satın alınmak üzere kıyyesi 50 paraya unların satılması Bingazi mutasarrıflı̆̆ınca teklif edilmiştir. Bu husus Meclis-i Mahsûs-1 Vükelâ'da görüşülmüştür. Alınan kararda, eğer beyan olunduğu üzere gelecek sene yerel ahali arpaya ihtiyaç duyar ise o zaman icabına bakılması için ilgili 360 bin kıyye unun mahallince müzayede yoluyla satılabileceği bildirilmiştir (BOA, DH. MKT, 9/11: 56).

Bingazi'ye gönderilen erzakla ahalinin iaşe ihtiyacının giderilmeye çalışıldığ 1 dönemde ahali ve memurlar arasında Tifüs hastalığının da ortaya çıktığı görülmektedir (BOA, DH. MKT, 9/11: 40 ve 44). Bu meselenin halledilmesi için de bölgeye tabipler ile birlikte tıbbi malzemenin gönderilmesi planlanmıştır. Fakat 7 Nisan 1893'te Sıhhiye Nezareti'nden verilen bilgiye göre, Bingazi'ye gönderilecek tıbbi malzemenin çeşidi ve miktarı konusunda bir süre hiçbir taraftan bilgi verilmediğinden ilgili malzeme de tedarik edilememiştir. Bir gün sonra, yani 8 Nisan 1893 günü saat dokuzda ise Bahr-i Cedid vapurunun hareket edeceği haber verilmiştir. Bu esnada Bingazi'ye gidecek tabipler de henüz İstanbul'da bulunmaktadır. Bu tabipler marifetiyle tıbbi malzemenin tedarik edilebileceği düşünülmüştür. Fakat ilgili saate kadar malzemenin vapura yetiştirilmesi mümkün görülmemiştir. Bunun üzerine malzemenin Selanik'ten tedarik edilerek Bingazi'ye gönderilmesi planlanmış ve bu hususta Selanik Vilayeti'ne de bilgi verilmiştir. Selanik'ten tıbbi malzemeyi almak üzere de Kavak Karantinası tabiplerinden olan ve Bingazi'ye gönderilecek sıhhi heyetin baştabibi olarak tayin edilen Bahr-i Cedid vapuruyla Selanik'e ulaştığında, gerekli olan tıbbi malzemeyle ilgili bir defteri vilayet idaresine verecek ve bunların temin edilmesinden sonra Bingazi'ye gönderecektir (BOA, DH. MKT, 9/11: 14; BOA, DH. MKT, 9/11: 15).

Bingazi'ye gönderilen tabip heyeti ile birlikte bulunmak ve eczacıllğa ait vazifeyi yerine getirmek üzere, aylık 1400 kuruş maaşla Eczacı Yanko Efendi'nin de tayin edildiği 8 Nisan 1893 tarihinde bildirilmiştir. Yanko Efendi'ye, işe başlama tarihinden memuriyet sonuna kadar verilecek maaşın 1893 senesi zuhurat gelirlerinden ödenmesi, bununla ilgili alınacak makbuz senedi ve varidat cetvellerinin de hazineye gönderilmesi istenmiştir (BOA, DH. MKT, 9/11: 36). 30 Ekim 1893 tarihine gelindiğinde ise, Yanko Efendi'nin görevini yerine getirerek İstanbul'a geri döndüğü öğrenilmektedir. Fakat görev süresine ait maaşı ile dönüş harcırahı olan 2.479 kuruşun, Maliye Nezareti veznesinin içinde bulunduğu bütçe sıkıntısından dolayı henüz ödenemediği, ancak 1893 yılı dâhiliye tahsisatından karşılanabileceği bildirilmiştir (BOA, DH. MKT, 9/11:53).

1893 yılı ortalarına gelindiğinde bir yıl önceki duruma göre şartların iyileştirildiği görülmektedir. Nitekim kasabada toplanmış olan ahalinin büyük bir kısmı hasat mevsiminin gelmesi dolayısıyla amelelik ve sair işler için ziraat alanlarına dağılmıştır. Toprak sahibi olanlardan bazılarının bir derece de olsa ihtiyaçlarının giderilmesi sağlanmıştır. Livada ortaya çıan tifüs hastalığı da bu günlerde yok olmaya yüz tutmuştur. Fakat bütün bunlara rağmen birtakım sorunlarla da karşı karşıya kalınmıştır. Özellikle çiftçiler için Konya ve İzmir'den gönderilen tohumluğun ziraat mevsiminden sonra ulaşması bir sorun teşkil etmiştir. Bu gecikmeden dolayı 1893 yılı hasadı, bir önceki seneye göre \%70 oranında azalmıştır. Dolayısıyla ziraattan mahrum kalan çiftçiler ile muhtaç durumdaki ahalinin ihtiyaçları tamamıla 
giderilememiş, kıtlık emarelerinin görülmesi devam etmiştir. Ayrıca Yanya ve Manastır vilayetlerinden gönderilmesi emredilen 500 bin kuruştan şu ana kadar 159.909 kuruş ulaştırılabilmiştir. Dolayısıyla 340.091 kuruş gönderilememiş, bu da ahali için başka bir sıkıntıya neden olmuştur (BOA, DH. MKT, 9/11: 40).

Bingazi'de meydana gelen kıtlık döneminde yetkililer, kıtlık hadisesinin sıkıntılarını hafifletmek amacıyla bazı yasak uygulamaları yürürlüğe koymuşlardır. Liva genelinde temel gıda maddelerindeki aşırı fiyat artışını engellemek maksadıyla emirler yayımlanmıştır. Örneğin hububat sahiplerinin elinde bulunan zahirenin, liva ahalisinin ihtiyaçlarını karşılamak amacıyla, diğer vilayetlere satışı yasaklanmıştır. Söz konusu uygulamanın maksadı, kıtlığın yaşandığı yerdeki zahire miktarının daha fazla azaltmasını engellemektir. Aynı zamanda Bingazi livası dâhilinde kuraklık ve kış nedeniyle dışarıya hayvan ihracının da yasaklandığı görülmektedir (BOA, DH. MKT, 7/17). Bunların yanı sıra kıtlık dönemlerinde problemlerin önlenmesi ve tamamen ortadan kaldırılması maksadıyla geçici idari birimler ve komisyonlar kurulmuştur. Örneğin kasaba merkezine toplanan kahtzedegân ahalinin temel ihtiyaçlarının karşılanması için bir iane komisyonu teşkil edilmiş ve yardım toplanmaya çalışılmıştır. (BOA, DH. MKT, 2014/16; BOA, BEO, 100/7486).

Bingazi ahalisinin huzura kavuşması ve kıtlık hadisesinin ortadan kaldırılması hususunda yetkililer tarafından mali açıdan alınan tedbirlerden biri de vergi indiriminin veya muafiyetinin sağlanmasıdır. Örneğin, kıtlık dolayısıyla Bingazi'ye gönderilecek erzak ve hububattan geçici olarak gümrük vergisi alınmaması 6 Ekim 1892 tarihli irade ile bildirilmiştir (BOA, DH. MKT, 2014/18); BOA, DH. MKT, 46/24). 1893 yllına gelindiğinde ise, Bingazi'de hasat mevsimine girilip kıtlığın etkileri yok olmaya yüz tuttuğundan, 1893 yılı Mayıs ayı başından itibaren ilgili verginin eskiden olduğu gibi alınmasına karar verilmiştir (BOA, DH. MKT, 46/24).

Kuraklık ve çekirge felaketlerine uğrayan Bingazi ahalisinin emlak vergisinden de muaf tutulması talep edilmiştir (BOA, DH. MKT, 2016/57). İlk etapta emlak vergisinden muaf tutulmaları talebinin uygun olmadığ (BOA, DH. MKT, 2009/12) belirtilmişse de daha sonra, Bingazi'de birkaç seneden beri devam eden kuraklık ve çekirgeden dolayı kıtlık yüz gösterdiğinden emlak vergisinin affolunduğu bildirilmiş̧tir. 1894 yılı başlarına gelindiğinde ise yeterli miktarda zahire gönderilmesinden sonra kıtlı̆̆ın azaltılmasıyla birlikte emlak vergisinin de tekrar alınmaya başlanması (BOA, DH. MKT, 9/11: 57) tebliğ edilmiştir.

Bingazi'deki ahalinin ihtiyaçlarının karşılanması için gönderilen zahirenin dağıtılmasında birtakım yolsuzlukların da meydana geldiği görülmektedir. Nitekim ihtiyaç sahiplerine dağıtılmak üzere daha önce 150 bin kile buğday ve arpa talep edilmiş ve hatta bu miktarın ihtiyaç duyulandan da çok az olduğu bildirilmiştir. Bunun üzerine üç defada 116 bin 297 kile buğday ve arpa gönderildiği halde bundan ancak 97.300 küsur kilesi ahaliye dağıtılmıştır. Geri kalanı başka alanlarda kullanılmış ve hatta bir kısmı satılmıştır. Bu durum ise, ihtiyaç sahiplerinin durumlarının layıkıyla tahkik edilmediğini ve lüzumundan çok daha fazla zahire istenildiğini ortaya çıkarmıştır. Hatta daha sonra talep edilmesi üzerine Selanik Vilayeti'nce satın alınarak gönderilen 360 bin kıyye unun da ahaliye dağıtılmayarak satılmış olması bunu doğrulamıştır. Dolayısıyla bölgedeki memurların ahalinin ihtiyaç durumunu dikkate almayıp alelade bir inceleme yaptığı ortaya çıkmış ve bu da lüzumundan fazla zahire alımına ve masrafa sebebiyet vermiştir. Neticede Selanik'ten sevk olunup bölgede satılan 360 bin kıyye un bedelinin Manastır ve Yanya vilayetlerine gönderilmesi ve sandık açı̆̆ı için kullanılması istenmiştir (BOA, ŞD, 353/37: 1).

Bingazi kahtzedegânı için daha önce satın alınıp bölgeye gönderilen 360 bin kıyye unun zamanında ihtiyaç sahiplerine dağıtılmadığı ve bozulmaya yüz tuttuğu daha sonra anlaşılmıştır. Bunun üzerine 360 bin kıyye unun mahallince müzayedeyle satılması ve bedelinin 
de livanın sandık açığı için kullanılması istenmiştir. Fakat bölgeden yapılan açıklamada, ilgili unun bir kısmının urbana dağıtıldığı ve elde de mevcut para olmadığı bildirilmiştir. Ancak bu açıklama, daha önce verilen bilgilerle tutarsız görülmüş ve ilgili satıştan elde edilen paranın biran önce bildirilmesi istenmiştir (BOA, ŞD, 353/37: 2). Bununla ilgili nasıl bir netice alındığına dair herhangi bir kayda ise rastlanmamıştır.

\section{Bingazi Kahtzedegânının Göçü}

Osmanlı Devleti'nde yaşanan kitlık hadiselerinin birçok olumsuz etkisi görülmektedir. Özellikle kıtlık dönemlerinde yaşanan iaşe sorunları ahali üzerindeki baskıyı arttırmıştır. Bu baskının etkisine bağlı olarak yaşanan gelişmelerden bir tanesi de zorunlu göç hareketi olmuştur. Bir bölgede özellikle coğrafi mekândan veya iklimden dolayı bir kıtlık olayı yaşanıyorsa ve bu olay etkisini uzun bir süre gösteriyorsa o bölge insanlarının bölgeyi terk ederek başka taraflara gitmesi doğaldır. Nitekim Bingazi ahalisinin de kıtlık ile mücadele edemediği vakitte, ikamet ettiği köyleri terk etmek ve başka yerlere gitmek suretiyle çözüm arayışına yöneldiği görülmektedir. Kıtlık hadiselerinin yol açtı̆̆ şartlardan ilk önce tarımla uğraşan ahalinin etkilendiği, bunların da bağlı oldukları kaza ve vilayet merkezine ya da başka bir vilayet dâhiline göç etmeye mecbur kaldığı tespit edilmiştir.

Bingazi'de yaşanan kıtlık ve pahalılık sebebiyle ahaliden bazıları kasaba merkezine iltica etmiştir. Bunların yeme-içme gibi temel ihtiyaçlarını karşılamak için bir komisyon teşkil edilmiştir. Bu komisyon vasıtasıyla yardım toplanmaya çalışılmıştır. Fakat bu girişimin tam olarak ihtiyacı karşılayamayacağı görülmüştür. Bu nedenle de kasabadaki izdihamı ve insanların kıtlıktan telef olmasını engellemek için başta bölgeye yakın olan Girit, Trablusgarp ve Cezair-i Bahri Sefid olmak üzere diğer vilayetlerden de biran önce yardım gönderilmesi gereği Bingazi mutasarrıflı̆̆ından bildirilmiş ve bu şekilde kahtzedegân ahalinin iaşelerini temin etmek maksadına hizmet edileceği ifade edilmiştir (BOA, DH. MKT, 2014/16; BOA, BEO, 100/7486).

Zaruret içerisinde bulunan Bingazi ahalisinden bir kısmı da başka vilayetlere göç etmek zorunda kalmıştır. Bu şekilde göç etmeye mecbur kalan ahali için arşiv belgelerinde ve basında Bingazi kahtzedegân, Bingazi muhaciri, kıtlıkzede tabirleri kullanılmıştır. Çalışmada ise, Bingazi kahtzedegânı tabiri esas alınmıştır. Nitekim bir kısım kahtzedegân, başta İzmir olmak üzere Adana, Beyrut, Suriye gibi farklı yerlere göç etmiştir. Başka vilayetlere göç etmek zorunda kalan ahalinin oralarda da sefalete düşmemeleri için gerekli tedbirlerin alınması ve ihtiyaçlarının giderilmesi merkezden bildirilmiştir (BOA, DH. MKT, 2020/19).

\section{Bingazi Ahalisinin Göç Ettiği Vilayetlerde Alınan Tedbirler ve Yapılan Yardımlar}

\subsection{Beyrut}

Bingazi'den Beyrut'a gelen kahtzedegânın bir kısmı vilayet dâhiline, bir kısmı da Suriye vilayetine gönderilmiştir. Şu durumda Beyrut merkezinde 200 Bingazi kahtzedegânı kalmış ve bunların iaşeleri yapılan yardımlarla karşılanmaya çalışılmıştır. Fakat bu şekilde iaşelerinin devamı mümkün görülmemiş ve Akka'ya gelen Cezayir muhacirleri gibi muhtaç olanlarına mal sandıklarından günlük altışar para verilmesi hususu Beyrut Vilayeti'nden 26 Ocak 1893 tarihinde bildirilmiştir. Buna cevaben Sadaret'ten gönderilen yazıda, Beyrut'a gelen kahtzedegânın iaşeleri hususunda mahalline izin verilmekle beraber ayrıca vilayetle görüşülerek bunların vatan-ı aslilerine iadesi hususunun da ele alınması istenilmiştir. Bunun dışında Bingazi'deki muhtaç ahalinin zahire ihtiyacı karşılanmakta ve yavaş yavaş sorun giderilmekte olduğundan artık göçün engellenmesine itina gösterilmesi Bingazi'ye ve Trablusgarp'a bildirilmiştir (BOA, BEO, nr. 149/11152). 
Beyrut'ta bulunan Bingazi kahtzedegânının iaşe edilmeleri hususunun fazla masraflı olduğu, bunların uzun müddet orada bırakılmasının da aralarında hastalık ortaya çıkmasına sebep olacağı ve bu nedenle de mahallerine iadesi Beyrut vilayetinden bildirilmiştir. Daha sonra bu husus Bingazi mutasarrıflığ 1 ile görüşülmüş ve bir karara varılmıştır. Buna göre, Bingazi henüz kuraklık ve kıtlığın etkisi altında bulunduğu için kahtzedegânın bu dönemde oraya iadesi uygun görülmemiştir (BOA, BEO, nr. 239/17907).

Beyrut'ta, 1893 yılı kış aylarında, tifüs ve çiçek hastalıkları görülmüştür. Bu hastalıkların tekrar etmesini engellemek amacıyla Bingazi kahtzedegânının dağınık halde bulundurulması ve şehrin temiz tutulması ${ }^{15}$ gerektiği bildirilmiştir. Nitekim İstanbul'da çıkan Le Moniteur Oriental ${ }^{16}$ gazetesine mahallinden yazılan bir mektupta da bu husus aynı şekilde dile getirilmiştir. Bütün bu verilen bilgiler üzerine bu yolda gerekli tedbirlerin alınması Beyrut'a yazılmıştır. Bingazi kahtzedegânının özellikle dağınık bir şekilde yerleştirilmeleri uygun bulunmuştur. Bu anlamda izdihamın önlenmesi için de mahalli idarece gerekli görüşmelerin yapılması ve ahalinin köylere, icap ederse de vilayet dâhilindeki liva ve kazalara dağınık bir halde yerleştirilmesi istenmiştir (BOA, BEO, 239/17907).

İhtiyaç sahibi olan ahaliye Beyrut Sandı̆̆g'ndan yevmiye verilmesine çalışılmıştır. Fakat zaman zaman yevmiyelerin kesintiye uğradığı belgelerden anlaşılmaktadır. Yevmiyenin kesilmesiyle birlikte de ahalinin çok zor duruma düştüğü görülmektedir. Nitekim bununla ilgili olarak Bingazi kahtzedegânından Abdurrahman ve Casim, sunmuş oldukları arzuhalde, yevmiyelerin kesilmesinden dolayı müşkül duruma düştüklerini ifade etmişler ve eskisi gibi düzenli bir şekilde verilmesine devam etmesini talep etmişlerdir. Nitekim bununla ilgili olarak merkezden vilayete gönderilen yazıda, durumun düzeltilmesi tebliğ edilmiştir (BOA, DH. MKT, 62/11).

\subsection{Suriye}

Kuraklık ve akabinde ortaya çıkan kıtlık sebebiyle Bingazi'den Beyrut'a gelen kahtzedegânın bir kısmı Suriye Vilayeti'ne gönderilmiştir (BOA, BEO, 149/11152). Yine bir kısım ahalinin Bingazi'den hareketle önce Girit'e gittiği tespit edilmiştir. Bir süre sonra da Girit'ten hareket edip İzmir'e ulaşmışlardır. Bunlardan 8 hane, Şam-1 Şerif'e gönderilme isteğinde bulunmuştur. Nitekim 8 Ağustos 1892 günü İzmir'den Beyrut'a doğru hareket edecek olan İdare-i Mahsusa vapurlarıla ücretsiz olarak nakilleri için İzmir acentesine merkezden emir verilmesi Aydın Vilayeti'nden talep edilmiştir. Neticede ilgili acenteye hemen emir verilmiş ve kahtzedegânın nakilleri gerçekleşmiştir (BOA, DH. MKT, 1989/95).

1893 yılı Nisan ayına gelindiğinde, Bingazi'den Suriye'ye göç etmiş olan kahtzedegânın memleketlerine dönmek arzusunda oldukları Suriye Vilayeti'nden haber verilmiştir. Bunun üzerine Sadaret'ten Bingazi'ye gönderilen 30 Nisan 1893 tarihli yazıda, kahtzedegânın dönmelerinde bir mani olup olmadığ hususu sorulmuştur. Mutasarrıf tarafından gönderilen telgrafta, liva dâhilinde bir süredir devam eden Tifüs illetinin şu aralık yok olmak derecesine geldiği, fakat kuraklık emarelerinin tamamıyla ortadan kalkmadığı belirtilmiştir. Daha önce kuraklık ve kıtlık nedeniyle iaşelerini temin etmek için gerek Suriye Vilayeti'ne, gerekse Beyrut

15 “Beyrut'ta kışın zuhur eden Tifüs ve Çiçek hastalıklarının men-i tekrarı zımnında şehrin temiz tutulması ve Bingazi muhacirlerinin dağını bulundurulması lüzumu..." İlgili yazı için bkz. (BOA, DH. MKT, 9/11: 48); (BOA, A. MKT. MHM, 531/4).

16 Mösyö Bilis'in imtiyaz sahibi olduğu gazete, Fransızca-İngilizce olarak Pazar günü dışında her gün yayımlanmıştır. Monitör Oryantal gazetesinde, 3 Mayıs 1893 tarihli çıkan mektupta, kentin merkezinde Bingazi kahtzedegânının toplanmasının tehlikesine ve sokakların bakımsızlığına dikkat çekilmiştir. Kış mevsiminde tifüs ve çiçek hastalıklarının görüldüğ̈̈, üçüncü bir felaketin gerçekleşmesini beklememek gerektiği belirtilmiştir. Beyrut şehrinin temiz tutulması vurgulanmıştır. Bu konuda belediye başkanlığındaki insanların, özellikle de başkanın, harekete geçmesi isteğinde bulunulmuştur. İlgili mektup için bkz. (BOA, A. MKT. MHM, 531/4) 
ve İzmir vilayetlerine göç etmiş olan ahalinin, geri dönmeleri durumunda, burada hasat vaktinin geçmesinden dolayı, geçimlerini temin edecek iş bulamayacakları; zaten kendileri muhtaç durumda oldukları için geçim ve iaşeleri hususunda merkez livaca müşkülata düşüleceği ve geçimleri sağlanamadığında da daha fazla zarurete ve istıraba maruz kalacakları bildirilmiştir. Bu nedenle de ahalinin dönmesine bir süre daha müsaade olunmaması istenmiştir (BOA, DH. MKT, 9/11: 44).

\subsection{Adana}

Kuraklık sebebiyle Bingazi kahtzedegânından 35 hane Adana'ya göç etmiştir. Bu kahtzedegân adına Abdullah imzasiyla bir arzuhal sunulduğu tespit edilmiştir. Arzuhalde, kahtzedegânın şu ana kadar Tarsus'ta temel ihtiyaçlarının karşılandığından ve iskân edilmek üzere de Adana'ya gelerek gördükleri arazide yerleşebileceklerinden bahsedilmiştir. Kahtzedegân için çift hayvanatı ve edevatı, tohumluk zahire ve diğer temel ihtiyaçlarının tedarik edilmesi gerekli görülmüştür. Bunların temin edilmesi için gerekli olan paranın da, daha sonra zirai hasılattan karşılanmak üzere, ya Ziraat Bankası'ndan ya da Hazine'den ödenmesi talep edilmiştir. Belirtilen bütün bu hususlar Adana Vilayeti İdare Meclisi'nde müzakere edilmiştir. Kahtzedegânın kendi hallerine bırakılması durumunda, buranın yabancısı olduklarından, ihtiyaç duydukları zirai malzemeyi tedarik edemeyip daha fazla sefalete düşecekleri öngörülmüştür. Neticede hükümetin, onların iyi hallerini sağlamaya mecbur olduğu belirtilmiş ve iskân ve zirai masraflarının yaklaşık 40-50 bin kuruşla halledilebileceği tahmin edilmiştir. Kahtzedegânın çiftçi sınıfından bulunmaları dolayısıyla da ilgili masrafın, 4 Haziran 1893 tarihli emirnamede tebliğ buyrulduğu üzere, Ziraat Bankası'ndan karşılanması icap etmiştir. Fakat bu karar hakkında Ziraat Bankası İdare-i Umumiyesi'nden vilayet Ziraat Bankası şubelerine bir tebligat icra olunmadığından ilgili şubelerden para ödenmesi mevcut durumda mümkün görülmemiştir. Dolayısıyla ilgili masraf bedelinin ya Ziraat Bankası şubesinden verilmesi için tebligat çıkarılması ya da tavizen Hazine'den karşılanmasına izin verilmesi Sadaret'e arz edilmiştir (BOA, DH. MKT, 7/41: 10).

Adana'da bulunan 35 hane Bingazi kahtzedegânın iskân ve zirai masrafları için talep edilen 40-50 bin kuruşun temin edilmesi yolunda gönderilen yazı görüşülmüştür. Beyrut'ta bulunan Bingazi kahtzedegânın, dönüşlerine izin verilmesi hakkındaki isteklerine nazaran Adana'dakilerin de dönme arzusunda bulunabilecekleri muhtemel olduğundan, eğer dönmek isterlerse para gönderilmesine gerek kalmayacağı düşünülmüştür. Bu durumun araştırılması ve eğer dönmek istemediklerini belirtirlerse vilayetin uygun yerlerine ikişer, üçer hane taksimle ve yerel ahalinin yardımıyla iskânları çaresine bakılması vilayete yazılmıştır. Buna cevaben vilayetten yazılan 17 Aralık 1893 tarihli yazıda, kahtzedegân içinde dönme arzusunda olmayıp iskân edilmek fikrinde olanlar da bulunduğu için bu gibilerle diğer muhacirlerden ihtiyaç sahiplerine yardım sağlanması hususunda yüzer paralık ve beşer kuruşluk olmak üzere vilayette toplam 40.000 kuruşluk iane biletinin basılmasına izin verilmesi talep edilmiştir (BOA, BEO, 347/25982).

Adana'da bulunan 35 hane Bingazi kahtzedegânı ile diğer muhacirlerin ihtiyaçları için yardım toplamak üzere beşer kuruşluk ve yüzer paralık olarak 40.000 kuruşluk bilet basılması talebine dair Adana Vilayeti'nden gönderilen yazı Meclis-i Mahsûs-1 Vükelâ'da görüşülmüştür. Buna göre, yardım toplanması hususunda bilet basılması birçok mahalde suiistimale uğraması nedeniyle bu yöntem kabul edilmemiş ve bilet basılmasından kaçınılması istenmiştir. Bunun yerine bazı vilayetlerde yapıldığı üzere bir defter düzenlenerek mahalli memurlar ile önde gelen kişilerin, yardımseverlerin isimlerinin yazılması ve gönül rızasıyla yardım toplanması uygun görülmüştür. Bu şekilde ne kadar yardım toplanır ise bu miktarın kahtzedegândan en 
ziyade fakir ve muhtaç olanlarına adilane bir şekilde taksim edilmesi bildirilmiştir (BOA, MV, 78/31; BOA, BEO, 347/25982). İlgili husus Sadaret tarafından da uygun görülmüş ve Dâhiliye Nezareti'ne havale edilmiştir (BOA, DH. MKT, 7/41: 14).

\section{4. İzmir}

Bingazi kahtzedegânının göç ettiği yerlerden bir tanesi de İzmir'dir. İzmir, XX. yüzyıla gelindiğinde yalnız Batı Anadolu ve Osmanlı Devleti'nin değil aynı zamanda bir bütün olarak Doğu Akdeniz bölgesinin önde gelen kentlerinden biridir (Kasaba, 1994, s. 1-11). Bu niteliği kazanmasında limanının ${ }^{17}$ çok önemli bir yeri vardır. Sahip olduğu limanı itibariyle özellikle Batı Anadolu'nun giriş kapısı niteliğindedir. Çeşitli yerlerinden farklı sebeplerle ayrılmak zorunda kalan pek çok ahali, temin ettikleri vapurlarla soluğu İzmir'de almıştır. Bir nevi muhacirlerin toplanma yerlerinden biri olmuştur. Nitekim Bingazi'de yaşanan kuraklık ve kıtlık neticesinde de bir kısım ahalinin İzmir'e göç ettiği tespit edilmiştir.

Kuraklık sebebiyle ortaya çıkan kıtlıkta zor durumda kalan bir kısım ahalinin Bingazi'den hareketle önce Girit'e gittiği tespit edilmiştir. Bir süre sonra da Girit'ten hareket edip İzmir'e ulaşmışlardır (BOA, DH. MKT, 1989/95). İzmir'e gelen Bingazi kahtzedegânı ile ilgili Hizmet' ${ }^{18}$ gazetesinde bazı haberler yer almıştır. Nitekim 1 Kasım 1893 tarihli habere göre, 1892 senesinde Bingazi'den İzmir'e yaklaşık 200 nüfus gelmiş ve iskân edilmek ${ }^{19}$ üzere de Nif nahiyesine ${ }^{20}$ gönderilmiştir. Fakat oranın hava ve suyuna uyum sağlayamadıklarından dolayı kısa bir süre önce yine İzmir merkezine dönmüşlerdir. Burada, Vilayet İdare Meclisi ve Sihhiye Komisyonu ${ }^{21}$ kararıyla eski ıslahhane binasına nakledilip yerleştirilmişlerdir. Daha sonra istirahatlerinin sağlanması için Tepecik'te kiralanan Han'a nakilleri sağlanmıştır. Burada belediye dairesi tarafından kendilerine yeterli miktarda ekmek ve diğer yiyeceklerden verilmiştir. Çıplak ve acınacak bir halde bulunmalarından dolayı da memurların gözetiminde çamaşır, elbise, pabuç ve hasırlar dağıtılmıştır. Aydın valisi olan Hasan Fehmi Paşa ${ }^{22}$ da Tepecik'i ziyaret ederek yardımların teslimi esnasında bizzat orada bulunmuştur. Bingazi kahtzedegânı, kendilerine gösterilen ilgiden ve yapılan yardımlardan dolayı memnun kalmış ve hem vali hem de padişaha hayır duasında bulunmuştur (Hizmet, nr. 699, 1 Kasım 1893).

1893 yılı, aynı zamanda İzmir'de Kolera salgınının da etkili olduğu bir yıldır. Nitekim 1893 yılı ortalarında İzmir'de etkili olan hastalık, özellikle Ağustos ayı itibariyle salgın halini alıp ciddi boyutlara ulaşmıştır. Bu salgının İzmir'de bulunan Bingazi kahtzedegânı arasında da etkili olduğu görülmektedir. Nitekim Tercüman-ı Hakikat gazetesinin 30 Ekim 1893 tarihli

17 XVII. yüzyılın başından itibaren Osmanlı İmparatorluğu, İzmir'in bir liman kenti olarak öneminin farkına varmaya başlamıştır. İzmir' in ticari olarak önemi bu yüzyıldan itibaren artmaya başlamıştır. Bunun nedenlerinden bir tanesi, XVI. yüzyılın ikinci yarısında Sakız Adası'nın Osmanlı kontrolüne geçmesinin ardından XVII. yüzyılın başında yabancı devletlerin konsolosluklarını İzmir'e taşımış olmasıdır. İkinci bir neden; İranlı ipek tüccarlarının savaş nedeniyle, daha önce Halep-İskenderun hattından yaptığı sevkiyatı İzmir'e kaydırmalarıdır. Böylece İzmir, Avrupalı ve Doğulu tüccarların buluşma noktası ve dünya ticaretinin bir kavşak noktası haline gelmiştir. Bkz. (Çiçek, 2006, s. 26-34).

18 İzmir'de, Cumartesi ve Çarşamba günleri olmak üzere haftada iki gün Türkçe olarak basılmıştır. İmtiyaz sahibi Ahmed Celaleddin Bey'dir. Bkz. (Salnâme-i Vilayet-i Aydın, 1312/1894: s. 166).

19 İzmir'de iskân işlerinden sorumlu memur, yani İskân-1 Muhacirin memuru Eşref Efendi'dir. Bkz. (Salnâme-i Vilayet-i Aydin, 1311/1893: s. 90).

20 Nif nahiyesi, İzmir kazasının doğu tarafında yer almaktadır. Kuzeyinde Manisa, doğusunda Kasaba (Turgutlu), güneyinde Bayındır, batısında İzmir ile sınırdır. Nüfusu, 8.881 erkek, 7.816 kadın olmak üzere 16.697'dir. Bkz. (Salnâme-i Vilayet-i Aydın, 1308/1891: s. 558).

21 İzmir Sıhhiye Komisyonu görevlileri; Reis: Vali Hasan Fehmi Paşa; Reis-i Sâni: Hamidiye Askeri Hastanesi Sertabibi Ali Bey, Kaymakam aza tabip Miralaylığından mütekait İshak Bey ile Fanu Bey; Sıhhiye Müfettişi Ali Rıza Efendi; Guraba Hastanesi Sertabibi Mustafa Bey; Karantina Tabibi Miçi Efendi'dir. Bkz. (Salnâme-i Vilayet-i Aydın, 1311/1893: s. 90).

22 (Salnâme-i Vilayet-i Aydın, 1311/1893: s. 88). Hasan Fehmi Paşa ile ilgili detaylı bilgi için ayrıca bkz. (Küçük, 1997, s. 322-323). 
sayısında, İzmir'de, ıslahhanede 1 ve Bingazi kahtzedegânından 1 olmak üzere 2 kişinin salgına yakalandığı bildirilmiştir (Tercüman-1 Hakikat, nr. 4596, 30 Ekim 1893). Yine gazetenin 3 Kasım 1893 tarihli sayısında, 5 gün evvel hastalanmış olan Bingazi kahtzedegânından Abdullah ile 6 gün önce şüpheli hastalığa yakalanmış olan Mekteb-i Sınai öğrencilerinden Abdurrahman'ın vefat ettikleri bildirilmiştir (Tercüman-1 Hakikat, nr. 4600, 3 Kasım 1893).

İzmir'de bulunan Bingazi kahtzedegânının ihtiyaçlarını karşılamak ve meydana gelen problemleri önlemek maksadıyla komisyonlar kurulmuş ve başarılı çalışmalar gerçekleştirilmiştir. Bu dönemde çalışmaları yürütecek olan Aydın Valisi Hasan Fehmi Paşa'dır. Nitekim Hasan Fehmi Paşa, Bingazi'den gelmiş olan 150 kadar evlad-ı Arab ile İzmir'de bulunan diğer fukaraya yardım edilmek üzere bir İane Komisyonu'nun teşkil edildiğini ve biletler basılmasına başlandığını haber vermiştir (BOA, Y. PRK. BŞK, 33/74:1). İzmir'in yerel basınından olan Hizmet gazetesinde de, Bingazi muhacirlerinin de içinde yer aldığı fukara için bir komisyon teşkil edildiği (Hizmet, nr. 702, 11 Kasım 1893) haberi yer almıştır. İzmir merkezinde söz konusu amaçlar doğrultusunda seçilen ve görevleri kendisine tebliğ edilen komisyon üyelerinden bazıları aşağıdaki tabloda olduğu gibidir (Bkz. Tablo 1).

Tablo 1: İzmir'de bulunan Bingazi ahalisine yardım için oluşturulan komisyonun üyeleri ${ }^{23}$

\begin{tabular}{|c|}
\hline Aza Seg(k)rizâde Abdülkadir Paşa \\
\hline Aza Uşakizade Sadık Bey \\
\hline Bank-1 Osmani, Kasaba Şimendiferi direktörleri ve Arabyan Efendi ile sair zevattan kişiler \\
\hline $\begin{array}{c}\text { Komisyon azalarından ve dava vekillerinden Corci Efendi, Arabyan Karabet Efendi, Haci } \\
\text { Kostaki Efendi }\end{array}$ \\
\hline
\end{tabular}

İane Komisyonu vasıtasıyla toplanan yardımlar, İzmir merkezinde bulunan kahtzedegâna dağıtılmıştır. Aynı zamanda hayırsever insanlardan arzu edenlerin de yardımda bulunabileceği belirtilmiştir. Nitekim bununla ilgili olarak birtakım yardımların yapıldığı görülmektedir. Örneğin, İzmir eşrafından ve Vilayet İdare Meclisi azasından Abdülkadir Paşa, muhtaç durumdaki ahaliye verilmek üzere 6 bin çift nân-1 azizi komisyona teslim etmiştir (Hizmet, nr. 695, 14 Ekim 1893). Abdülkadir Paşa, nân-ı azizin yanı sıra fukaraya 150 mecidiye nakden akçe yardımında da bulunmuştur (Hizmet, nr. 696, 18 Ekim 1893). Yine bu yönde olarak padişah tarafından 250 Lira yardım ihsan buyrulmuş ve bunun vilayete havalesi hususu da Hazine'ye bildirilmiştir (BOA., Y. PRK. BŞK, 33/74: 2). Bununla ilgili olarak Hizmet gazetesinde yer alan haberde, "geçen sene kaht u galâ sebebiyle bu taraflara hicret etmiş olan Bingazi ahalisinin önemli ihtiyaçları için 250 Osmanlı Lirası ihsan buyrulmuştur." (Hizmet, nr. 700, 4 Kasım 1893) haberi yer almıştır.

İdari görevliler kıtlık nedeniyle zor durumda kalan halka yardım etmek için değişik yöntemler de uygulamışlardır. Bu yöntemlerden bir tanesi de 1893 yılında İzmir'de kıtlıktan zarar gören ve sıhhati iyi olmayan, muhtaç durumda olanlar için aşağıda örneği görülen iane biletlerini satışa sunmak olmuştur (Bkz. Resim 1).

${ }^{23}$ (Hizmet, nr. 702, 11 Kasım 1893); (Hizmet, nr. 708, 2 Aralık 1893). 


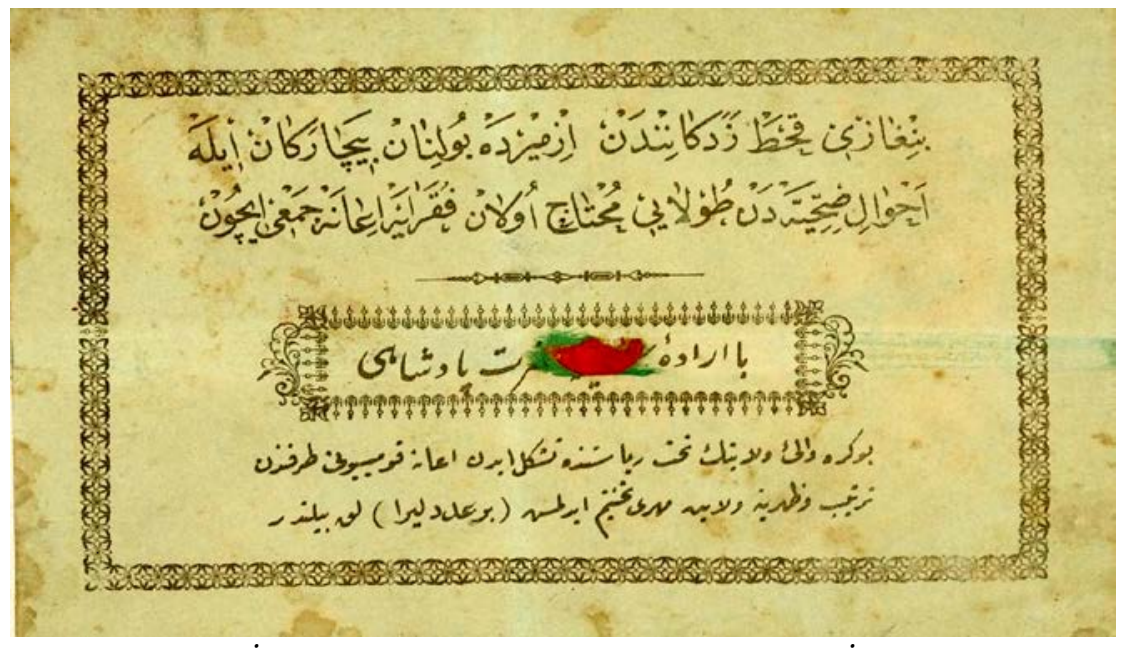

Resim 1: İmir'de Kitliktan Zarar Gören ve Sihhati İyi Olmayan Muhtaçlara Yardım Toplamak İçin Çıkarılan Biletler (BOA, Y.PRK. KOM, 8/50)

Seg(k)rizâde Abdülkadir Paşa ile Uşakizade Sadık Bey, Bank-ı Osmani, Kasaba Şimendiferi direktörleri ve Arabyan Efendi ile sair kişilerden oluşan İane Komisyonu, 9 Kasım 1893 Perşembe günü vilayet belediye dairesinde vali Hasan Fehmi Paşa'nın idaresi altında toplanarak müzakerelerde bulunmuştur. Toplantı neticesinde 10, 20, 50, 100 kuruşluk olmak üzere 5 bin adet bilet basılmasına karar verilmiştir. Yardım etmek konusunda iyiliksever, cömert ahalinin geri durmayacağına, biletlerin kısa bir sürede satılacağına inanılmıştır (Hizmet, nr. 702, 11 Kasım 1893). Söz konusu menfaat için vali tarafından devlet görevlileri ve durumu iyi olan ahali teşvik edilmiş ve önemli miktarda yardım elde edilmesi hedeflenmiştir.

İane Komisyonu 30 Kasım 1893 Perşembe günü vali Hasan Fehmi Paşa'nın idaresi altında toplantı yapmıştır. Bu toplantıya katılan komisyon azalarından Seg(k)rizâde Abdülkadir Paşa 40, Uşakizâde Sadık Bey 60, komisyon azalarından ve dava vekillerinden Corci Efendi 20, Arabyan Karabet Efendi 40, Haci Kostaki Efendi 15 Osmanlı Lirası olmak üzere nakdi yardımda bulunmuşlardır. Buna dair Hizmet gazetesinde yer alan haberde, bundan sonra yardımda bulunacak yardımsever insanların ilan edileceği bildirilmiştir (Hizmet, nr. 708, 2 Aralık 1893).

İane Komisyonu, Vali Hasan Fehmi Paşa'nın başkanlığında 5 Aralık Salı günü de vilayet dairesinde toplanarak 310 Osmanlı Lirası miktarında yardım toplanmıştır (Hizmet, nr. 709, 6 Aralık 1893). Yine Bingazi kahtzedegânı ve muhtacını için 14 Aralık Perşembe günü yapılan toplantıda, Sahlepçizâde Hacı Ahmed Efendi 40, Ispartalızâde 30, Balyozzâde 30, Arslanzâde 10 ve Nakıb Efendi 1 Osmanlı Lirası yardımında bulunmuşlardır. Bunlarla birlikte toplanan yardımların miktarı 535 Liraya ulaşmıştır (Hizmet, nr. 712, 16 Aralık 1893).

İlerleyen tarihlerde yardımlar yapılmasına ve peyderpey bilet alımlarına devam edilmiştir. Vali Hasan Fehmi Paşa tarafından kimseye ağır gelmeyecek bu yardım kampanyasının düzenlemesi sonucunda fakir ve ihtiyaç sahiplerine yardım eli uzatılabilmiştir. Bu yardım kampanyası için İzmir'in Hizmet gazetesine düşen görev ise bu gelişmeleri şükranlıkla ifade etmek ve ahaliyi teşvik etmek olmuştur. Diğger taraftan kıtlık hadiselerine yakalanan ahalinin de kendilerine yapılan yardımlar karşılığında vefakâr davranarak gerekli makamlara teşekkürü ihmal etmedikleri ve padişaha dua ettikleri görülmüştür.

Netice olarak, zaruret içerisinde bulunan Bingazi ahalisinin bir kısmı İzmir başta olmak üzere Adana, Beyrut, Suriye gibi farklı vilayetlere göç etmek zorunda kalmıştır. Osmanlı Hükümeti de göç etmek zorunda kalan bu ahalinin ihtiyaçlarının giderilmesi için gerekli 
tedbirleri almaya çalışmıştır. Özellikle yerel idareler nezdinde önemli çalışmalar yürütülmüştür. Burada, ayrıca bir hususa daha değinmek gerekmektedir. Bu da yaşanan bu kuraklık hadisesinden önce ve sonra bölgeye muhacir iskân edilmesine çalışılmasıdır. Bir taraftan göç veren bir yer olan Bingazi, diğer taraftan muhacir iskân edilmesine çalışıldığı bir yer olmuştur. Nitekim bölgeden gönderilen raporlar doğrultusunda, eksik olan insan gücünün sağlanması için Kafkas ve Rumeli muhacirlerinin bölgeye iskân edilmesine çalışılmıştır. Fakat bölgenin uzaklığı, ekonomik sıkıntılar ve coğrafi şartların farklılığı nedeniyle muhacirlerin gitmek istememesi bu girişimi başarısız kılmıştır. Bu yönde önemli adımların atıldığı ve bazı önemli sonuçların elde edildiği iskân girişimi ise Girit Müslümanları konusunda olmuştur. Girit'te yaşanan siyasi ve toplumsal olaylar nedeniyle bir kısım ahali Bingazi'ye göç etmek zorunda kalmıştır. Bu ilk etapta kendi imkânlarıyla göç eden muhacirlerin vermiş olduğu bilgiler de bir sonrakilerin bölgeye gitmesinde etkili olmuştur. Nitekim Osmanlı Hükümeti de bölgenin aktif hale gelmesi ve üretime açılması için muhacirlerin iskânını bir fırsat olarak görmüş ve bunu değerlendirmek için çalışmalarını başlatmıştır. ${ }^{24}$ İskân sürecinde, yani 30 Ocak 1901 tarihinde muhacirlerden bazılarının bir arzuhal sunduğu tespit edilmiştir. ${ }^{25} \mathrm{Bu}$ arzuhal, Bingazi'deki kuraklık durumuna dair bilgi vermesi açısından önemlidir. Arzuhalde, çiftçi sınıfından olan muhacirler, geçimlerinin, ziraat edecekleri hububat ile bağ ve zeytin mahsulüne bağlı olduğunu belirtmişlerdir. Bunların yetişmesi ise zaman alacağından bu aralıkta nasıl geçineceklerini sorgulamışlardır. Özellikle yağmurun sekiz on senede bir defa görüldü̆̆̈̈ne dikkat çekerek, yağmursuzluk nedeniyle ziraat olunacak arpa ve buğday mahsulleri yetişmediği takdirde umrândan yoksun bir yerde hallerinin neye varacağını düşündüklerini, bunun da bölgede iskân edilmeleri yönündeki cesaretlerini kırdığını ifade etmişlerdir (BOA, DH. MHC, 48/71: 2-2). Dolayısıyla muhacirler de bölgedeki yağmur azlığına dikkat çekmişler ve bunun neden olacağı şartlarda geçimlerini sağlamada sıkıntı çekecekleri endişesini taşımışlardır.

\section{SONUÇ}

Bingazi, bulunduğu coğrafya ve iklim şartları itibariyle farklı tarihlerde şiddetli kuraklık afetlerine maruz kalmıştır. Nitekim 1892-1893 yıllarında bölgede meydana gelen kuraklık hadisesi de bölgede fazlasıyla etkili olmuş ve kısa bir sürede kıtlık derecesine ulaşmıştır. Ortaya çıkan bu kuraklıktan dolayı hasılat mahvolmuş, ahali ve urban perişan bir hale düşmüştür.

Kuraklığa bağlı olarak yaşanan kıtlıkta buğday ve arpa bulunamamış, bu da un, ekmek gibi temel ihtiyaçlarda ve tohumlukta kıtlı̆̆a neden olmuştur. Bu çeşit kıtlıklar hem adı geçen ürünlerin fiyatlarının artmasına hem de üretici-tüketici bundan olumsuz etkilendiği için diğer metalarda da fiyat artışına sebep olmuştur. Dolayısıyla bu vaka toplumun alım gücünün düşmesi ile genişleyen bir sıkıntı halini almıştır.

XIX. yüzyılın son çeyreğinde Osmanlı Devleti, bir taraftan siyasi, sosyal, idari ve askerî gelişmelere uyum sağlamaya çabalarken diğer taraftan kıtlık hadiseleriyle mücadele etmek durumunda kalmıştır. Kıtlık dönemlerinde ve özellikle kıtlığın etkili olduğu bölgelerde müdahaleci bir politika izlemiştir. Nitekim Bingazi'de yaşanan kıtlık hadisesi esnasında da hem

24 XIX. yüzyılın sonunda Girit Adası'nda Rum asilerce yapılan yağma ve katliam olayları sonrasında servetlerine el konulan, can güvenlikleri kalmayan Müslüman halk, Anadolu, Ege Adaları, Balkanlar ve Arap coğrafyasına göç etmek zorunda kalmıştır. Bu göç dalgasının önemli bir bölümü Batı Anadolu kıyılarına doğru gerçekleşmiştir. Ancak imkân bulanlar da Trablusgarp Vilayeti'ne kaçmışlardır. Özellikle Bingazi ile Derne arasında kalan zeytinlik alan muhacirler için cazip görünmüştür. Girit’te yaşanan olaylar, Girit Müslümanlarının zorunlu göçü ve Bingazi mutasarrıflı̆̆ı dâhilinde yürütülen iskân çalışmaları ile ilgili detaylı bilgi için bkz. (Menekşe, 2018).

25 Arzuhalin sonunda 55 muhacirin isimleri ile birlikte geldikleri şehirler de yazmaktadır. Bu anlamda, 19 Kandiyeli, 24 Hanyalı, 4 Resmolu bulunmaktadır. Bazılarının şehirleri yazılmamıştır. Ayrıca muhtarlar da muhacirler içinde yer almıştır. Arzuhal metni ve muhacir mühürleri için bkz. (BOA, DH. MHC, 48/71: 2-2). 
merkezden hem de diğer vilayetlerden bölgeye yardım gönderilmesine çalışılmıştır. Özellikle çevre vilayetlerden zahire tedarikinin sağlanmasına gayret edilmiştir. Tüccar ve önde gelen kişilerin zahire alımı teşvik edilmiştir. Yine, zahirenin dışa ihracı yasaklanmış, böylece temel gıda maddelerinin saklanması ve piyasadan çekilmesini önlenmiş ve kıtlık hadisesinin etkisi azaltılmaya çalışılmıştır.

Bingazi'de meydana gelen şiddetli kuraklıktan dolayı kıtlık olayının yaşanması ve bu olayın etkisinin uzun bir süre devam etmesi neticesinde insanlar bulundukları yerleri terk ederek başka taraflara gitmeye başlamıştır. İlk etapta ahaliden bazıları kasaba merkezine iltica etmiştir. Özellikle iaşe temini konusunda çözüm arayışına yönelmişlerdir. Nitekim iaşelerini temin etmek için kasabada bir komisyon teşkil edilmiş ve yardım toplanmasına çalışılmıştır.

Zaruret içerisinde bulunan Bingazi ahalisinden bir kısmı da, yemeklik ve tohumluk zahirenin yetersiz kalmasından dolayı, başka vilayetlere göç etmek zorunda kalmıştır. Arşiv vesikalarında Bingazi muhaciri, Bingazi kahtzedegânı olarak adlandırılan bu insanlar, İzmir başta olmak üzere Adana, Beyrut, Suriye gibi farklı yerlere göç etmişlerdir. Diğer vilayetlere göç etmek zorunda kalan bu insanların oralarda da sefalete düşmemeleri için gerekli tedbirlerin alınması ve ihtiyaçlarının giderilmesi ilgili mahallere bildirilmiştir. Nitekim bu mahallerde muhacirlerin ihtiyaçlarının karşılanması için yardım komisyonları kurulmuş, nakit desteği için biletler basılmış, zengin insanlar yardım etmeye teşvik edilmiştir. Böylelikle hem yerel idare hem de hükümet eliyle muhtaç durumdaki ahalinin ihtiyaçlarının giderilmesine çalışılmıştır. Kendilerine yapılan yardımlar karşısında vefakâr davranan Bingazi ahalisi de gerekli makamlara teşekkürü ihmal etmemiştir.

\section{SUMMARY}

The Ottoman State, which incorporates different climates and land conditions, has never been able to stay away from natural disasters. The famines, earthquakes, fires, grasshopper invasions, heavy rains and winters in the Ottoman geography have seriously threatened human life. It has caused important social, environmental and economic damages. One of the disasters that caused these losses was long drought.

Drought, which is a natural climate phenomenon, is when rains are less than expected in an area. Therefore, there have been arid periods not only in the regions with constant low rainfall but also in rainy regions. In order to talk about drought, the time when precipitation is below normal or below expected level should last at least one season or one year. Therefore, drought occurs in a certain region with precipitation less than normal for a certain period of time. It can occur anywhere at any time. According to many researchers, the most important natural disaster among thirty-one natural disasters counted is drought.

Drought is also considered to be the slowest developing, insidious and most dangerous natural disaster that causes the most comprehensive socio-economic damages. Drought has important impacts on the environment and social life. Its effects on the environment damage the water and water quality in the soil, the plant areas shrink, penetrate the natural lives of the animals. Among its effects on social life, there is a shortage of food, accordingly an increase in impoverishment and subsequent migration.

Drought has several impacts on social life. One of them is famine. In general, famine is referred to as "an advanced level of widespread hunger". If a few specific definitions are included, famine can also be defined as "a wide-ranging nutrient deprivation where deaths from starvation or starvation occur". In the Turkish Language Association dictionary, for famine; "Drought, war, etc. The product is not grown for reasons and hunger arising from it ".

It is also considered as a disaster because it is not known before, where and under what 
conditions the famines will occur due to natural conditions and give fatal results. Although natural causes such as flood, fire, drought, earthquake, grasshopper infestation, epidemic diseases, extreme cold and temperatures are effective in the emergence of this disaster, human causes such as banditry incidents, riots and wars can also be effective.

Drought was seen in the Ottoman state at different times, as in many parts of the world. As a matter of fact, the Ottoman State dominated the lands with a wide range of climate and land conditions. In some regions of the Ottoman State, famine events were encountered at different periods. From the 16th century to the late 19th century, famine incidents occurred in many parts of Anatolia, the Balkans, Crimea, North Africa, Syria and Cyprus. These famines had an adverse effect on the Ottoman State in many ways. On the other hand, the Ottoman State, on the other hand, tried to produce short, medium and long term solutions as a requirement of the social state understanding.

In this study, the drought in Benghazi in 1892-1893 and its reflection on the public were emphasized. As a matter of fact, drought and related famine events were encountered in different periods of history in Benghazi. Benghazi has been exposed to severe drought disasters on different dates due to its geography and climate conditions. As a matter of fact, the drought incident that occurred in the region between 1892 and 1893 was also very effective in the region and reached a degree of famine in a short time. Due to this drought, revenues were destroyed, and the people became urban and miserable.

Wheat and barley could not be found in the shortage due to drought, which caused basic needs such as flour and bread and seed shortage. These kinds of famines not only increased the prices of the mentioned products but also caused an increase in prices in other commodities as the producerconsumer was negatively affected. Therefore, this case has become an expanding problem with the decrease of the purchasing power of the society.

In the last quarter of the 19th century, the Ottoman State struggled to adapt to political, social, administrative and military developments, and on the other hand had to fight famine events. It followed an interventionist policy in times of famine, and especially in regions where scarcity was effective. As a matter of fact, during the famine incident in Benghazi, it was tried to send aid to the region from both the center and other provinces. In particular, efforts were made to ensure the supply of products from the surrounding provinces. Merchant and prominent people are encouraged to purchase products. Again, the export of products is prohibited, thereby preventing the storage and withdrawal of basic foodstuffs and reducing the impact of the famine incident.

Due to the severe drought in Benghazi, as a result of the famine incident and the effect of this event for a long time, people left the region and started to go to other parties. In the first place, some of the inhabitants took refuge in the town. In particular, they turned to seeking solutions for food supply. As a matter of fact, a commission was established in the town to provide their food and aid started to be collected.

Some of the people in Benghazi, who are in distress, had to migrate to another province due to the insufficiency of edible and seed products. These people, who were called Benghazi immigrants in archive documents, emigrated to different places such as Izmir, Adana, Beirut and Syria. These people, who had to emigrate to other provinces, were reported to the relevant districts to take the necessary precautions and eliminate their needs so as not to fall into misery. As a matter of fact, aid commissions were established in these areas to meet the needs of the refugees, tickets were issued for cash support, and the help of rich people was encouraged. Thus, efforts were made to meet the needs of the people in need, both by the local administration and by the government. The people of Benghazi, who have been loyal to their help, did not neglect the necessary authorities. 


\section{KAYNAKÇA}

a) Arşiv Belgeleri

BOA, Sadâret Mektubî Kalemi Mühimme Odası Evrakı (A. MKT. MHM), nr. 531/4.

BOA, Babıâli Evrak Odası (BEO), nr. 8220; 100/7486; 102/7578; 105/7820; 107/7956; 149/11152; 239/17907; 3277/245706; 3416; 256134; 347/25982; 47/3495; 82/6103; 84/6299; 82/6103; 107/7956; 110/8220; 347/25982.

BOA, İrade Hususi (İ. HUS), nr. 7/16.

BOA, Dâhiliye Nezareti Muhacirin Komisyonu Evrakı (DH. MHC), nr. 48/71.

BOA, Dâhiliye Nezareti Mektubî Kalemi Evrakı (DH. MKT), nr. 2024/93; 2031/40; 1414/75; 1423/26; 1989/95; 2007/116; 2009/12; 2014/16; 2014/18; 2016/57; 2020/19; 2038/60; 2049/62; 2614/68; 46/24; 9/11; 62/11; 7/17; 7/41; 7/41;9/11;9/11.

BOA, Dâhiliye Nezareti Şifreli Evrakı (DH. ŞFR), nr. 392/124; 395/62.

BOA, İrade Dâhiliye (İ. DH), nr. 1301/29.

BOA, İrade Maliye (I. ML), nr. 1/9; 3/37.

BOA, Meclis-i Vâlâ (MV), nr. 78/31.

BOA, Şura-yı Devlet (ŞD), 353/37.

BOA, Yıldız Tasnifi Perakende Evrakı Mabeyn Başkitabeti (Y. PRK. BŞK), nr. 33/74.

BOA, Yıldız Tasnifi Perakende Evrakı Komisyonlar Maruzatı (Y. PRK. KOM), nr. 8/50.

\section{b) Resmî ve Süreli Yayınlar}

Meclis-i Mebusan Zabıt Ceridesi, 118. İn'ikâd, Devre 1, Cilt 6, İçtimai Sene 2, 7 Haziran 1326/20 Haziran 1910 Pazartesi Oturumu.

Meclis-i Mebusan Zabıt Ceridesi, 37. İn'ikâd, Devre 1, Cilt 2, İçtimai Sene 2, 26 Kânunusani 1325/8 Şubat 1910 Salı Oturumu.

Meclis-i Mebusan Zabıt Ceridesi, 5. İn'ikâd, Devre 1, Cilt 1, İçtimai Sene 4, 10 Teşrinievvel 1327/23 Ekim 1911 Pazartesi Oturumu.

Salnâme-i Vilayet-i Aydın, 14.Def'a, İzmir-Aydın Vilayeti Matbaası, H. 1311/M. 1893.

Salnâme-i Vilayet-i Aydın, 15. Def'a, İzmir-Aydın Vilayeti Matbaası, H. 1312/M. 1894.

Salnâme-i Vilayet-i Aydın, Cilt-i Sâni, İzmir-Aydın Vilayeti Matbaası, H. 1308/M. 1891.

Hizmet, nr. 695, 2 Teşrinievvel 1309/ 14 Ekim 1893.

Hizmet, nr. 696, 6 Teşrinievvel 1309/ 18 Ekim 1893.

Hizmet, nr. 699, 20 Teşrinievvel 1309/ 1 Kasım 1893.

Hizmet, nr. 700, 23 Teşrinievvel 1309/ 4 Kasım 1893.

Hizmet, nr. 702, 30 Teşrinievvel 1309/ 11 Kasım 1893.

Hizmet, nr. 708, 20 Teşrinisani 1309/ 2 Aralık 1893.

Hizmet, nr. 709, 24 Teşrinisani 1309/ 6 Aralık 1893.

Hizmet, nr. 712, 4 Kânunuevvel 1309/ 16 Aralık 1893.

Tercüman-ı Hakikat, nr. 4596, 18 Teşrinievvel 1309/30 Ekim 1893.

Tercüman-ı Hakikat, nr. 4600, 22 Teşrin-i evvel 1309/3 Kasım 1893.

c) İnceleme-Araştırma ve Kaynak Eserler

Ali ve Ahmed Nuri. (1301). Afrika-i Osmanîden Trablusgarb ve Bingazi ve Fizan kıt'alarna dair coğrafí ve istatistikî ve tarihî ve siyasî ve askerî malumâtı havî bir risale, İstanbul Üniversitesi Kütüphanesi Nadir Eserler Bölümü, Tarihi Yazma Nr. 5002.

Ali Tevfik. (1318). Memâlik-i Osmaniyye coğrafyası, coğrafya-yı umumiyye, III, İstanbul: Kasbar Matbaası. Armaoğlu, F. (2006). 19. yüzyll siyasi tarihi (1789-1914), İstanbul: Alkım Yayınevi.

Asan, H. (2018). "Bitlis Vilayeti'nde yaşanan kıtlık hadiseleri (1887-1894)", Turkish Studies History, 13/8, (Bahar), s. 1-17.

Atalay, İ. (2011). Resimli ve haritalı dünya coğrafyası, İstanbul: İnkılâp Yayınları.

Bayar, Y. (2013). 1873-1875 Orta Anadolu kıtlı̆̆̆, (Basılmamış Yüksek Lisans Tezi), İstanbul: Marmara Üniversitesi Türkiyat Araştırmaları Enstitüsü.

Coşgel, M. (2007). "Agricultural productivity in the early Ottoman Empire", Research in Economic History, 24, p. 161-187.

Cox, G. W. (1981). "The ecology of famine: an overview", Famine: Its Causes, Effects, and Management, (Ed. J.R.K. Robson), New York: Gordon and Breach Science Publications, p. 5-18. 
Çetinkaya, Ü. (2009). “Divan şiirinde sosyal hayattan yansımalar: Necatî ve Hayretî’nin arpa kıtlığını anlatan iki manzumesi", Türkbilig, 17, s. 47-55.

Çiçek, Ü. (2006). "İzmir limanının tarihsel gelişimi", AREGE Bülten, (Haziran), s. 26-34.

Demirtaş, M. (2004). “XVI. yüzyılda meydana gelen tabii afetlerin İstanbul'un sosyal ve ekonomik hayatına etkilerine dair bazı misaller", Atatürk Üniversitesi Sosyal Bilimler Enstitüsü Dergisi, IV/2, (Erzurum), s. 37-50.

Devellioğlu, F. (2007). Osmanlıca-Türkçe ansiklopedik lûgat, Ankara: Aydın Kitabevi.

Erinç, S. (1992). “Bingazi”, Türkiye Diyanet Vakfi İslam Ansiklopedisi (DİA), VI, (İstanbul), s. 181-183.

Erler, M. Y. (2002), “XIX. yüzyıldaki bazı doğal afetler ve Osmanlı yönetimi”, Türkler, XIII, (Ankara), s. $762-771$.

Erler, M. Y. (2012). Osmanlı Devleti'nde kuraklık ve kıtlık olayları(1800-1880), İstanbul: Libra Kitap.

Gehedr, A. (1996). Osmanl resmî kaynaklarna göre Trablusgarb Vilayeti (1282-1312/1865-1894), (Basılmamış Yüksek Lisans Tezi), İstanbul: İstanbul Üniversitesi Sosyal Bilimler Enstitüsü Yakınçă̆ Anabilim Dalı.

Gráda, C. Ó. (2007). "Making famine history”, Journal of Economic Literature, XLV, (March), p. 5-38.

Gökhan, İ. (1998). XIII. ve XIV. yüzyıllarda Mısır ve Suriye"de krizler, kıtlıklar ve vebalar, (Yayınlanmamış Doktora Tezi), Elazığ: Fırat Üniversitesi Sosyal Bilimler Enstitüsü.

Hionidou, V. (2002). "Why do people die in famines? Evidence from three island populations", Population Studies, 56/1, (Mar.), p. 65-80.

İnalcık, H. (1990). “Köy, köylü ve imparatorluk”, V. Milletlerarası Türkiye Sosyal ve İktisat Tarihi

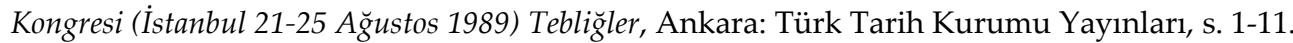

Kadıŏlu, M. (2011). “ Kuraklık kıranı”, Cumhuriyet Bilim Teknik Dergisi, (İstanbul Mart), s. 17-24.

Karademir, Z. (2014). Imparatorluğun açlıkla imtihanı (Osmanlı toplumunda kıtlıklar 1560-1660), İstanbul: Kitabevi Yayıncılık.

Karal, E. Z. (2011). Osmanl tarihi (birinci meşrutiyet ve istibdat devirleri (1876 - 1906), Cilt VIII, Ankara: Türk Tarih Kurumu Basımevi.

Kasaba, R. (1994). “İzmir”, Doğu Akdeniz'de Liman Kentleri, İstanbul: Tarih Vakfı Yurt Yayınları, s. 1-11.

Kılıç, O. (2002). “Osmanlı Devleti'nde meydana gelen kıtlıklar”, Türkler, X, Editörler: Hasan Celal Güzel, Kemal Çelik, Salim Koca, Yeni Türkiye Yayınları, (Ankara), s. 718-730.

Koloğlu, O. (2001). Arap kaymakam, İstanbul: Aykırı Yayıncılık.

Küçük, C. (1997). "Hasan Fehmi Paşa”, Türkiye Diyanet Vakfı İslam Ansiklopedisi (DİA), XVI, (İstanbul), s. $322-323$.

Madra, Ö. (2014). “Önsöz: Akad'ın laneti-Suriye cehennemi-gezegenin geleceği”, İklim Değişikliği ve Kuraklık, (Yazarlar: Ümit Şahin-Levent Kurnaz), İstanbul: Istanbul Policy Center Sabancı University-Stiftung Mercator Initiative.

Mehmed Nuri ve Mahmud Naci. (2012). Trablusgarp: hedefteki ülke Libya'nın tarihi, Yayına Hazırlayanlar: Ahmet Kavas, Abdullah Erdem Taş, Muhammed Tandoğan), İstanbul: Tarihçi Kitabevi.

Menekşe, M. (2018). Girit Müslümanlarının zorunlu göçü: sevk ve iskân (1897-1913), Muğla Sıtk1 Koçman Üniversitesi Sosyal Bilimler Enstitüsü Tarih Anabilim Dalı Basılmamış Doktora Tezi, Muğla.

Ömer Subhi. (1307). Trablusgarb ve Bingazi ile Sahra-yı Kebir ve Sudan merkezi, İstanbul Üniversitesi Kütüphanesi Nadir Eserler Bölümü, Tarihi Yazma Nr. 4261, İstanbul.

Öz, M. (1999). “Osmanlı klasik döneminde tarım”, Osmanlı, III, Ankara: Yeni Türkiye Yayınları, s. 6673.

Özdeğer, Y. (2008). “XIX. yüzyıl sonlarında meydana gelen bir kuraklık ve kıtlık hadisesi ile bunun sosyo-ekonomik sonuçları”, Karadeniz Araştırmaları, Sayı: 19, Güz-2008, s. 87-96.

Rossi, E. (1979). “Trablus”, Milli Ĕ̆itim Bakanlığı İslam Ansiklopedisi (İA), XII/1, (İstanbul), s. 445-455.

Shaw, S. J. ve E. K. Shaw. (2010). Osmanlı İmparatorluğu ve modern Türkiye, Cilt II, İstanbul: E Yayınları.

Şahin, Ü. ve L. Kurnaz. (2014). İklim değişikliği ve kuraklık, İstanbul: Istanbul Policy Center Sabancı University-Stiftung Mercator Initiative.

Şemseddin Sami. (1318). Kâmûs-ı Türkî, II, İstanbul: İkdam Matbaası.

Tekin, S. (2015). “19. yüzyılın sonu 20. yüzyılın başlarında Batı Anadolu'da yaşanan kuraklık olayları", The Journal of Academik Social Science Studies, 33, (Bahar), s. 329-341. 
Ülgener, F. S. (1984). Darlık buhranları ve İslam iktisat siyaseti, Ankara: Mayaş Yayınları.

Veinstein, G. (2001). “Karadeniz'in kuzeyinde büyük 1560 kuraklığı: Osmanlı yetkililerinin durumu algılayışı ve gösterdikleri tepkiler", Osmanlı Imparatorluğu'nda Doğal Afetler, Edt. Elizabeth Zachariadou, İstanbul: Tarih Vakfı Yurt Yayınları, s. 297-306.

1911-1912 Osmanlı-İtalya harbi ve Kolağası Mustafa Kemal. (1985). Yayına Hazırlayan: Genelkurmay Askeri Tarih ve Stratejik Etüt Başkanlığı, Ankara: Kültür ve Turizm Bakanlığı Yayınları. 